\title{
A Scanning Electron Microscopic Study on the Appendage Morphology of Astacus leptodactylus (Eschscholtz, 1823) and Pacifastacus leniusculus (Dana, 1852) (Crustacea: Decapoda: Astacoidea)
}

\author{
Estudio en Microscopio Electrónico de Barrido sobre el Apéndice Morfológico del Astacus leptodactylus \\ (Eschscholtz, 1823) y Pacifastacus leniusculus (Dana, 1852) (Crustacea: Decapoda: Astacoidea) \\ Muzaffer Mustafa Harlioglu
}

HARLIOGLU, M. M. A scanning electron microscopic study on the appendage morphology of Astacus leptodactylus (Eschscholtz, 1823) and Pacifastacus leniusculus (Dana, 1852) (Crustacea: Decapoda: Astacoidea). Int. J. Morphol., 26(4):1035-1051, 2008.

SUMMARY: This study compares the morphology of rostrum, pereipods 1,2,4 and mouthparts of juvenile Astacus leptodactylus with those of Pacifastacus leniusculus. Differences in morphology were observed, in particular with regard to the mouthparts e.g. including setal armature and number of teeth on the mandible. In general, the shape of the rostra in the two species is similar in that both taper to a point with a pair of sharp spines distally. Laterally the rostrum of A. leptodactylus is bordered by a regular row of setae, which is not so well defined in P. leniusculus. The observations also showed that in addition to an increase in size, changes in morphology in the feeding apparatus between the developmental stages of the two species were present. It was concluded that both species have similar rostra, but different setal patterns and there are differences between the two species in the armature of mouthparts as development progresses. Therefore, important differences in the morphology of mouthparts between P. leniusculus and A. leptodactylus and in the different stages of the species might cause a difference in the feeding behavior and food choice of the species.

KEY WORDS: Appendages; Astacus; Crayfish; Mouthparts; Pacifastacus; Scanning electron microscope.

\section{INTRODUCTION}

The signal crayfish, Pacifastacus leniusculus (Dana, 1852), is native to north-western North America inhabiting lakes, streams and rivers (Lowery \& Holdich, 1988) as well as saline waters (Henry \& Wheatly, 1988; Holdich et al., 1997). It is also tolerant to environmental extremes such as temperature and various pollutants (Firkins, 1993). Pacifastacus leniusculus is similar in many ways to Astacus astacus (Linnaeus, 1758) and consequently has proved popular alternative since the decline of the latter species due to the introduction crayfish plague into many Europe catchments (Holdich, 1999). The signal crayfish is identified by its red colour, and large robust chela including a white to turquoise patch on the claw gives this crayfish its common name. This North American crayfish has been introduced into many European watersheds.

The narrow-clawed crayfish, Astacus leptodactylus (Eschscoltz, 1823) is a native of Turkey and near East Europe.
It occupies a similar niche to that of $P$. leniusculus. However, in addition to streams, rivers, lakes, and ponds, it also inhabits swamps. Thus, it is sometimes called the swamp crayfish (Cherkashina, 1975; Köksal 1988, Harlioglu \& Harlioglu, 2004). Astacus leptodactylus is commercially exploited either as imports or from introduced populations distributed widely across Europe, exception of the Iberian Peninsula and Nordic countries (Harlioglu \& Holdich, 2001; Holdich 2002; Skurdal \& Taugbol, 2002). This species is identified by its long claws (mainly typical for males) and is commonly named the narrow-clawed or Turkish crayfish (Harlioglu, 1996).

Pacificastacus leniusculus and A. leptodactylus have become popular experimental animals. The Turkish crayfish has been subjected to biochemical, physiological and ecological studies where as physiology, ecology, reproduction and distribution have been subjects for $P$. leniusculus (Duvic \& Soderhall, 1990; Firkins, 1993; Guan, 
1995; Warner \& Green, 1995; Harlioglu, 1996). The main reason for these researches is because the signal crayfish has been introduced into most European countries for aquacultural and wild-stocking purposes (Lowery \& Holdich). However, in recent years there has been an increase in the number of studies concerning aquaculture and immunology of P. leniusculus as the species carries crayfish plague. Consequently, many investigators have concentrated on its immune system (e.g. Persson et al., 1987; Duvic \& Soderhall; Aspan \& Söderhall, 1991; Kopacek et al., 1993) and the implications for susceptible crayfish when this species has been translocated (Holdich \& Reeve, 1991).

Descriptions of P. leniusculus and A. leptodactylus have been given in a few keys (Curra, 1967; Pennack, 1978; Laurent \& Forest, 1979; Brodski, 1983; Gledhill et al., 1993; Vigneux et al., 1993) and Andrews (1907) illustrated the appendage structure of the signal crayfish. Recently, $P$. leniusculus was chosen as a model in the description of functional morphology of crayfish by Holdich \& Reeve (1988), and Holdich (1992) also reviewed the early postembryonic development of astacid, cambarid and parastacid crayfish. However, to date no scanning electron microscopic studies have highlighted the morphology and appendage structure of these two species in any detail.

Differences in the morphology and structure of mouthparts and pereiopods of crayfish are useful in classifying them for systematic purposes. For example, variations in the rostra, chelae, mandibles and third maxillipeds were used by Hobbs (1987) to classify species of Astacoides. Variations in chelae were also considered to determine taxonomic differences between Orconectes propinquus and O. obscurus by Tierney (1982). Morphological differences of the western North American crayfish species of Pacifastacus have been used to assign species into the subgenera Pacifastacus and Hobbsastacus (Bouchard, 1977).

Scanning electron microscopy has been used to study the external morphology of mouthparts, pereiopods and pleopods in a variety of decapod crustaceans. For example, the functional morphology of mouthparts and pereiopods has been observed in the Norway lobster Nephrops norvegicus by Farmer (1974) and the shrimp Atya innocous by Felgenhauer \& Abele (1983); in the prawn Panaeus merguiensis by Hindley \& Alexander (1978) and Alexander et al. (1980). Moreover, observations on the morphology and structure of feeding apparatus and distribution of setae in lobsters have mainly reported for Homarus americanus and H. gammarus (Solon \& Cobb, 1980). In addition to these, there are also some studies on anostracan crustaceans. For example, Mura \& Caldo (1993) have studied the structure of the molar surface of the mandibles in the shrimp
Branchinella spinosa. A similar study has been carried out on brine shrimp by Tyson \& Sullivan (1981).

The aim of the present study is to compare the differences and similarities in the morphology of appendages (rostrum, carapace, first pereiopod, second pereiopod, fourth pereiopod) and mouthparts (third maxilliped, second maxilliped, first maxilliped, mandible, maxillule and maxilla) of A. leptodactylus and P. leniusculus under the scanning electron microscope. In addition, the development of mouthparts in stage 1, 2 and 3 juveniles of the two species was also evaluated.

\section{MATERIAL AND METHOD}

Juveniles of different stages (first, second and third) and juveniles $12 \mathrm{~mm}$ in carapace length (CL) of P. leniusculus and A. leptodactylus were scanned. The samples were reared under laboratory conditions in clean containers instead of keeping them in concrete tanks which have a muddy floor would therefore make them dirty and unsuitable for photography. After individuals had moulted, they were sacrificed when their body became hard enough to dissect and before they lost any appendages. To sacrifice the samples, they were placed in a freezer for ten minutes. Then they were preserved in 70 percent alcohol.

Mouthparts and appendages were removed under a light microscope. After dissection, the selected body parts of $12 \mathrm{~mm}$ length (carapace) juveniles were air dried for approximately 12 hours at room temperature $(18 \pm 10 \mathrm{C})$. Because the stage 1, 2 and 3 juveniles were too delicate to apply air drying technique, the critical-point drying technique was applied for them.

Then, the selected appendages were attached to aluminum stubs with silver colloidal paint and coated with gold using a Polaron Sputter Coating Unit E5100. Finally, to view the body parts the stubs were set up in a JSM-840 scanning electron microscope operated at either 10,15 or $25 \mathrm{KV}$.

The terminology used is taken from Holdich \& Reeve (1988). The segments of the appendages are named from attachment point as: coxa, basis, ischium, merus, carpus, propodus, and dactylus with a terminal unguis.

To show differences and similarities in the rostrum, carapace, second pereiopod, fourth pereiopod, third maxilliped, second maxilliped, first maxilliped and mandible between $P$. leniusculus and A. leptodactylus, $12 \mathrm{~mm}$ (carapace length) juveniles were compared. Third stage juveniles were also used 
to show differences in the first pereiopod (cheliped) between the two species. The development of stage 1,2,3 and $12 \mathrm{~mm}$ (CL) juveniles was also evaluated within and between the two species (except the maxilla of stage 1 juveniles).

Due to the delicate nature of the mouthparts and appendages of juveniles it proved sometimes very difficult to prepare them for scanning electron microscopy. Consequently, some of the photographs exhibit charging (brightness). In the description below only the differences and similarities which were apparent between the two species are described.

\section{RESULTS}

Differences and similarities in the morphology of appendages and mouthparts: Differences and similarities in the morphology of appendages and mouthparts were found between the species.

Rostrum and carapace. In general, the shape of the rostra in the two species is very similar. They taper to a point, but near the apex a sharp spine occurs on either side (long arrows in Fig. 1 for P. leniusculus and Fig. 2 for A. leptodactylus).

The sides of the rostrum of A. leptodactylus are bordered by a regular row of setae. This row of setae on the rostrum of $\mathrm{P}$. leniusculus is not as regular as that of $A$. leptodactylus. (see short arrows in Fig. 1 for P. leniusculus and Figure 2 for A. leptodactylus).

Although both species have pairs of post-orbital ridges on each side of the rostrum, A. leptodactylus also has a prominet tubercle on shoulder of carapace (see arrow in Fig. 4); this is absent in P. leniusculus (Fig. 3).

Mandible. There are more teeth on the incisor lobe of the mandible of $P$. leniusculus (see arrow in Fig. 39 for $P$. leniusculus and Fig. 40 for A. leptodactylus).

Maxillue. The length of setea on the protopod of $P$. leniusculus is greater than that of A. leptodactylus. In addition, unlike $P$. leniusculus, in $A$. leptodactylus the tip of the protopod of the maxillule has long setae (arrows in Fig. 47 for P. leniusculus and Fig. 48 for A. leptodactylus).

Maxilla. Setea on the edge of the protopod lobes are present in A. leptodactylus. These setea are not present on the protopod lobes of $P$. leniusculus (see arrows in Fig. 55 for $P$. leniusculus and Fig. 56 for A. leptodactylus).

First maxilliped. A difference occurs in the length of setae

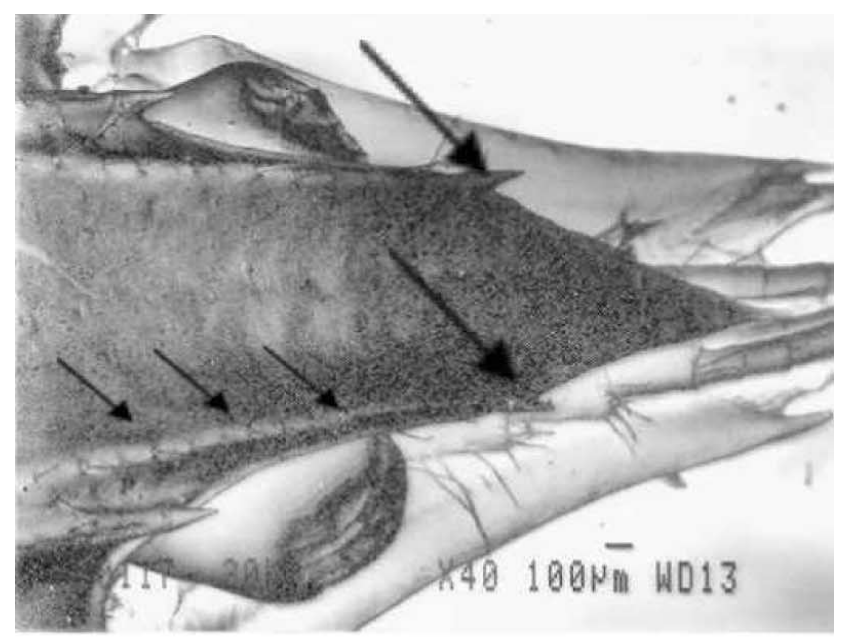

Fig. 1. Setae on the sides of the rostrum in $12 \mathrm{~mm}$ (CL) $P$. leniusculus.

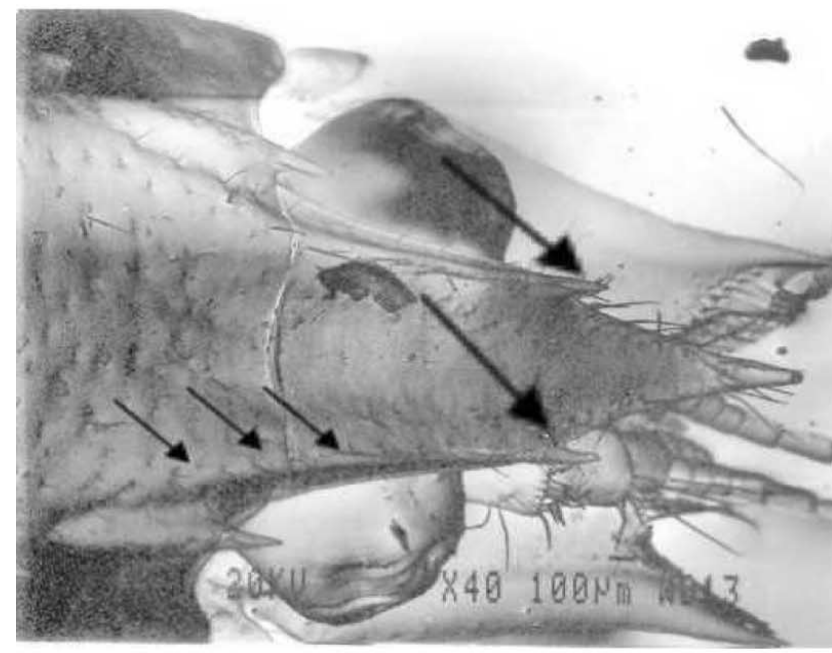

Fig. 2. Setae on the sides of the rostrum in $12 \mathrm{~mm}$ (CL) A. leptodactylus.

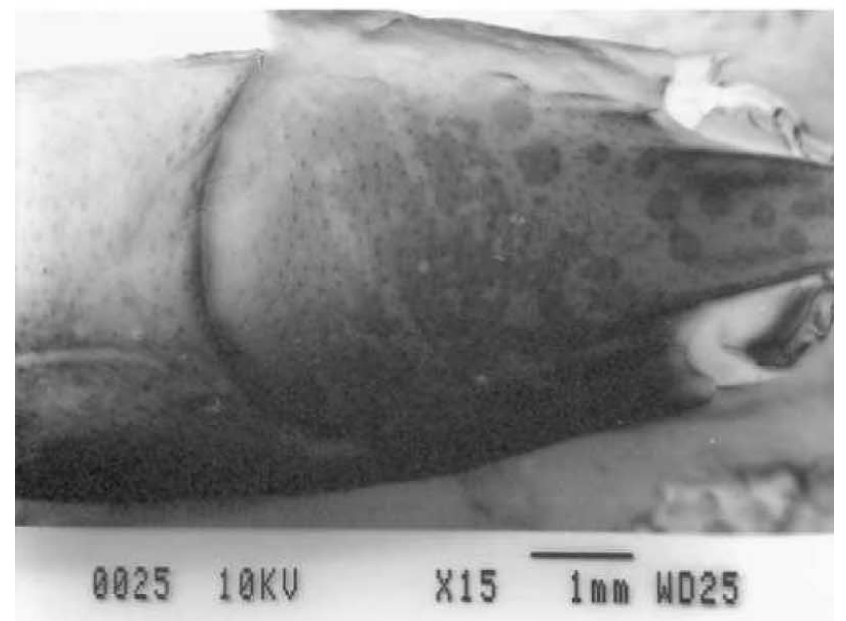

Fig. 3. Absence of prominent tubercle on the shoulder of carapace in $12 \mathrm{~mm}(\mathrm{CL})$ P. leniusculus. 

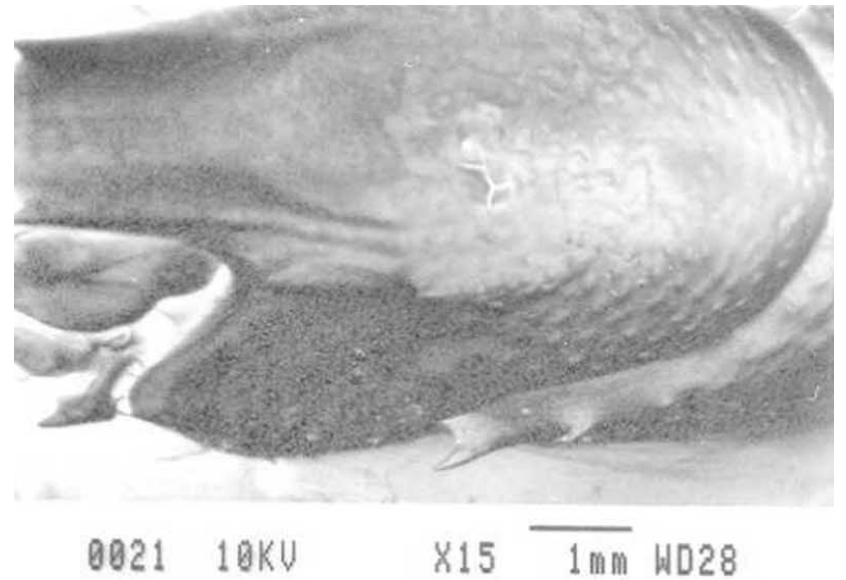

Fig 4. Presence of prominent tubercle on the shoulder of carapace in $12 \mathrm{~mm}(\mathrm{CL})$ A. leptodactylus

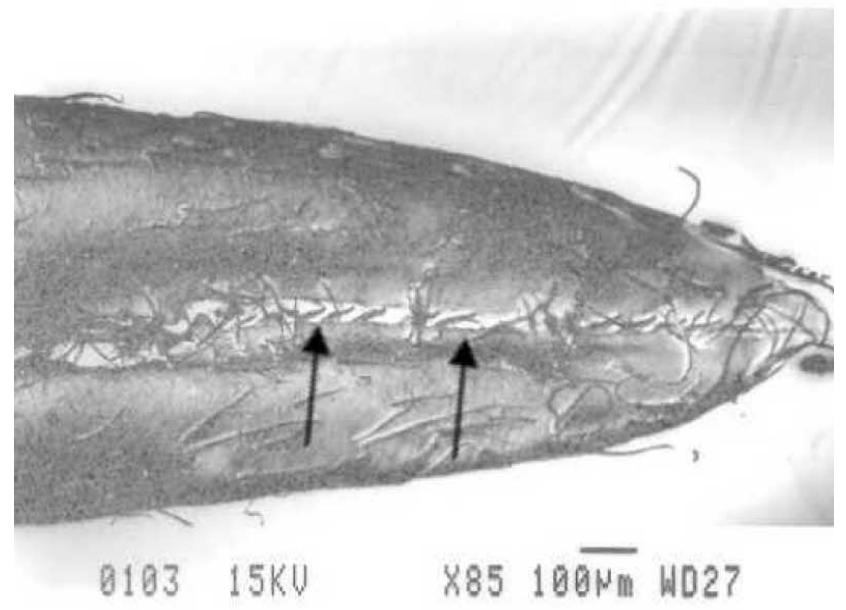

Fig. 5. Dactylus and propodus of the first pereopod in stage $3 P$. leniusculus

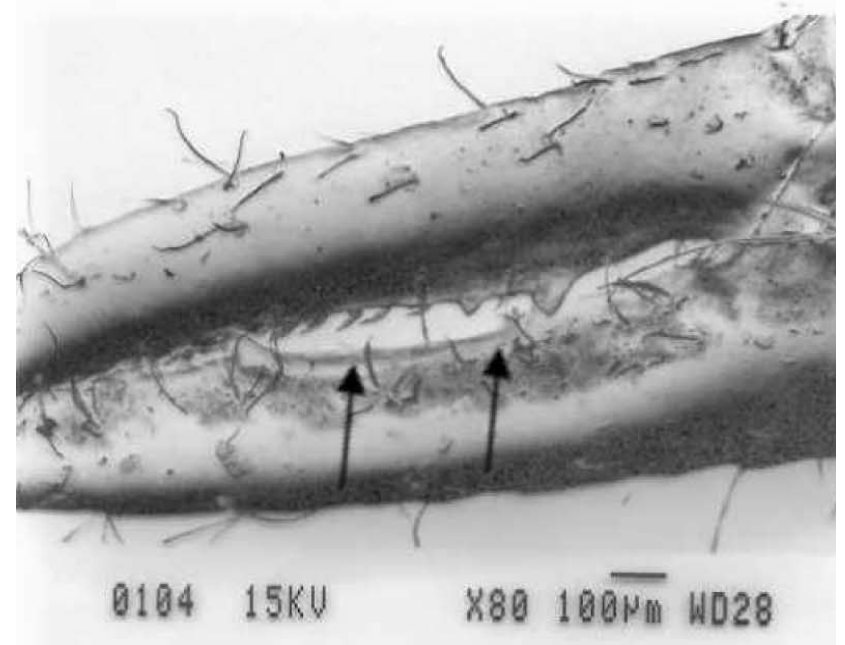

Fig. 6. Dactylus and propodus of the first pereopod in stage $3 \mathrm{~A}$. leptodactylus. on the exopod. Bigger setae are present on the exopod of $P$. leniusculus (Fig. 31 for P. leniusculus and Fig. 32 for $A$. leptodactylus).

Second maxilliped. Compared to A. leptodactylus, more abundant and very close setae are present on the endopod of P. leniusculus (see arrows in Fig. 23 for P. leniusculus and Fig. 24 for A. leptodactylus).

Third maxilliped. A spine is present on the second and third segments of the third maxilliped in A. leptodactylus (see arrows in Fig. 13). These spines are not present in $P$. leniusculus (Fig. 14).

The number and distribution of teeth are also different on the crista dentata (first segment) of the two species. There are more teeth on the crista dentata of P. leniusculus (see arrows in Fig. 15 for P. leniusculus and Fig. 16 for $A$. leptodactylus).

Cheliped (first pereiopod). The gap between the dactylus and propodus of the cheliped is wide in A. leptodactylus and the margins are serrated. The gap is narrower in P. leniusculus and the inner edges of the dactylus and propodus are not so serrated (see arrows in Fig. 5 for P. leniusculus and Fig. 6 for A. leptodactylus).

There is a row of setae on the propodus of the cheliped in A. leptodactylus (see long arrows in Fig. 8), but there is no a row of setae on the cheliped in P. leniusculus (Fig. 7).

The carpus of P. leniusculus has setae, but that of A. leptodactylus has not. Also, the shape of the spine on the edge of the carpus is different in the two species, that of A. leptodactylus being much larger (Fig. 7 for P. leniusculus and Fig. 8 for A. leptodactylus, see short arrow).

Second pereiopod. A difference was found regarding the propodus and dactylus between the species. Although A. leptodactylus has an unguis at the tip of propodus and dactylus, this unguis does not appear in P. leniusculus (Fig. 9 for P. leniusculus and Fig. 10 for A. leptodactylus, see arrow).

Fourth pereiopod. More abundant setae are present on the ventral side of the propodus of $A$. leptodactylus than those of P. leniusculus (see arrow in Fig. 11 for P. leniusculus and Fig. 12 for A. leptodactylus).

Juvenile development of Pacifastacus leniusculus and Astacus leptodactylus: In addition to an increase in size, developmental changes in morphology in the feeding apparatus of $P$. leniusculus and A. leptodactylus were found 


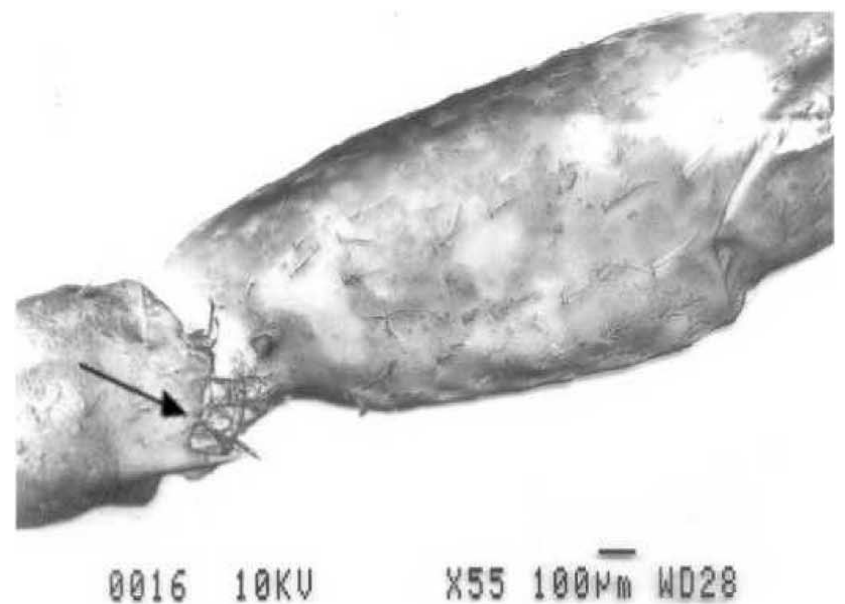

Fig. 7. Propodus and carpus of the first pereopod in stage $3 \mathrm{P}$. leniusculus.

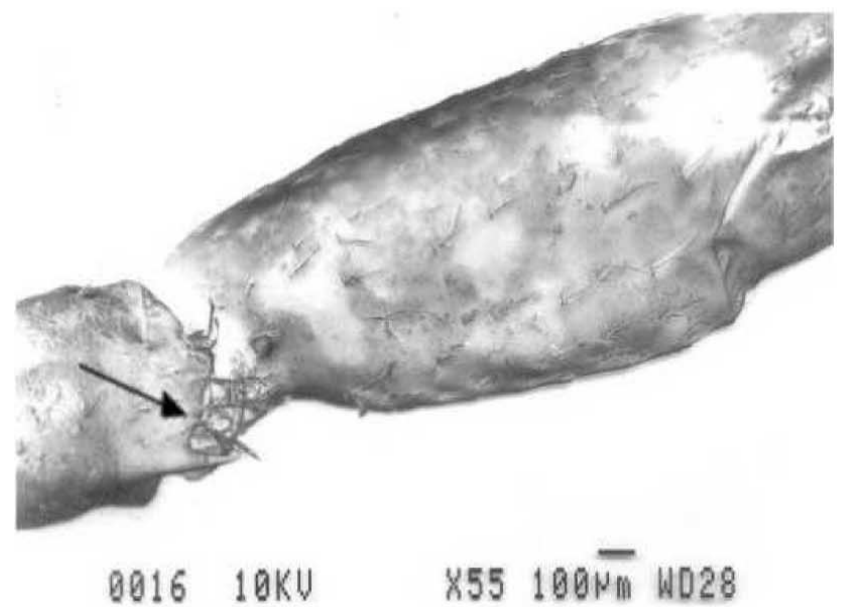

Fig. 8. Propodus and carpus of the first pereopod in stage $3 \mathrm{~A}$. leptodactylus.

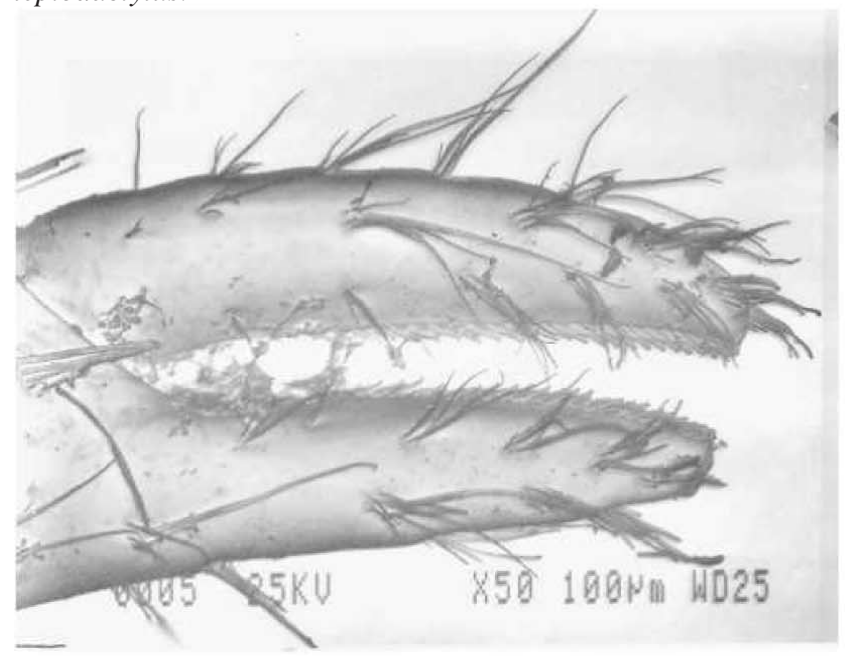

Fig. 9. Propodus and dactylus of second pereopod in $12 \mathrm{~mm}$ (CL) P. leniusculus.

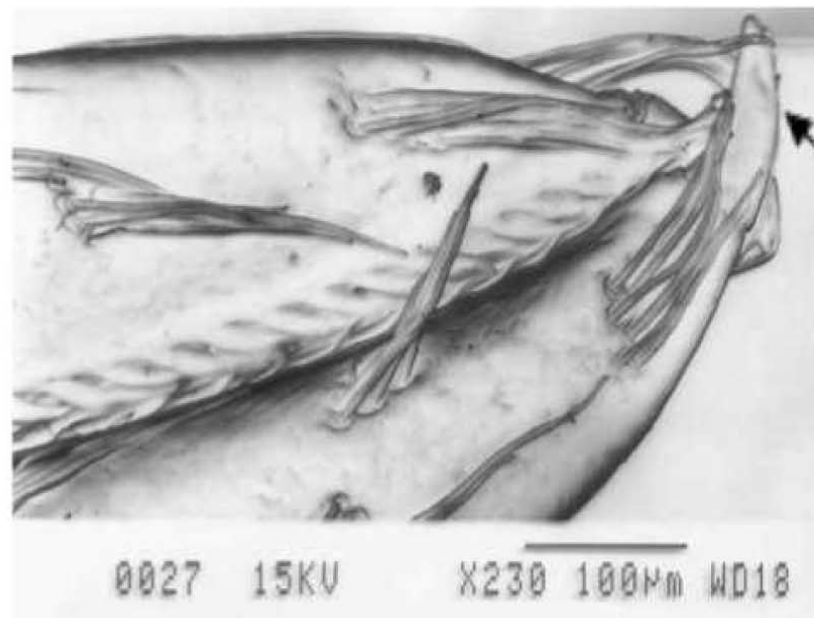

Fig. 10. Propodus and dactylus of second pereopod in $12 \mathrm{~mm}$ (CL) A. leptodactylus.

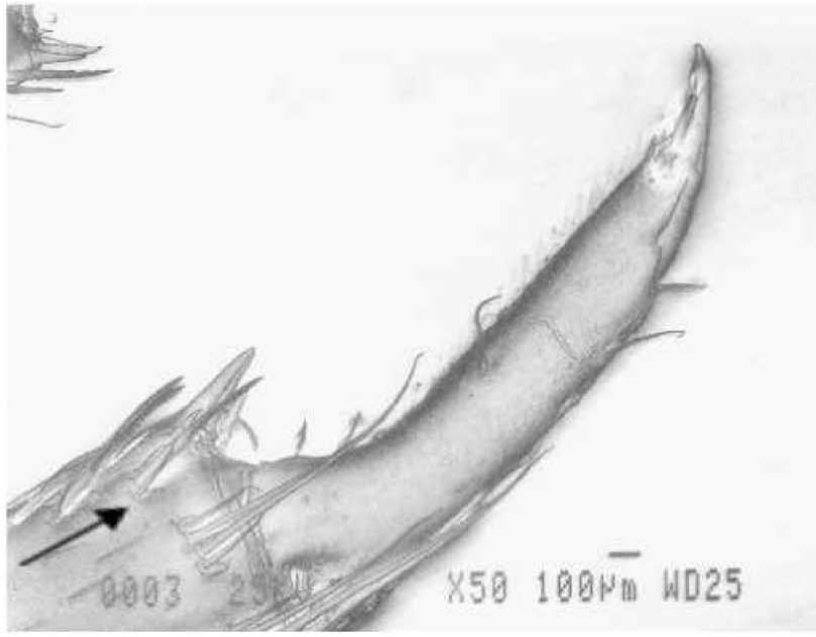

Fig. 11. Ventral side of propodus of fourth pereopod in $12 \mathrm{~mm}$ (CL) P. leniusculus.

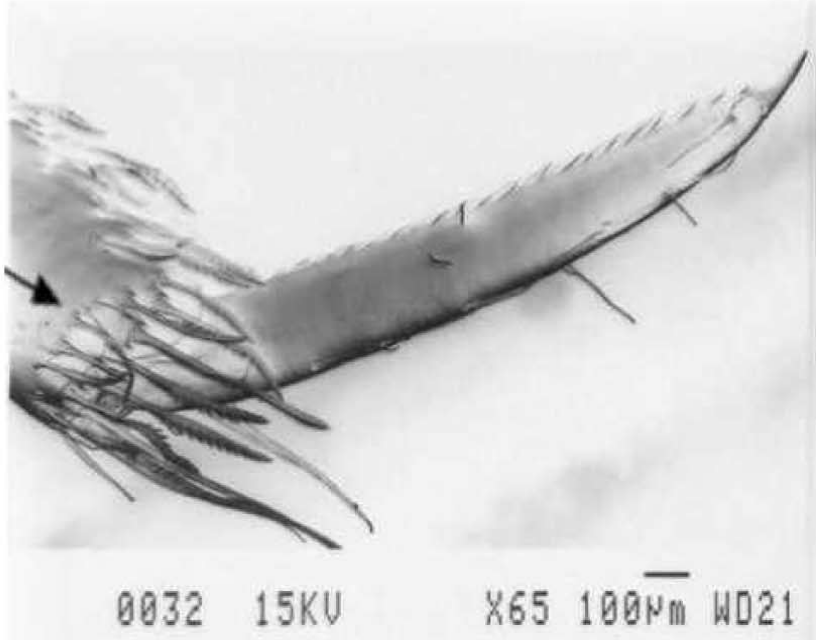

Fig. 12. Ventral side of propodus of fourth pereopod in $12 \mathrm{~mm}$ (CL) A. leptodactylus. 
HARLIOGLU, M. M. A scanning electron microscopic study on the appendage morphology of Astacus leptodactylus (Eschscholtz, 1823) and Pacifastacus leniusculus (Dana, 1852) (Crustacea: Decapoda: Astacoidea). Int. J. Morphol., 26(4):1035-1051, 2008.

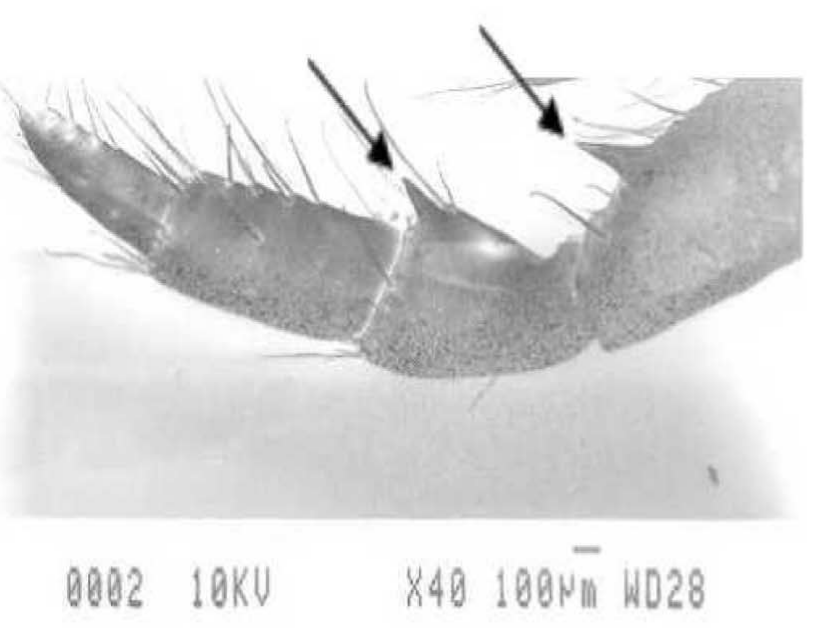

Fig. 13. Second, third, fourth and fifth segment of the third maxilliped in $12 \mathrm{~mm}$ A. leptodactylus.

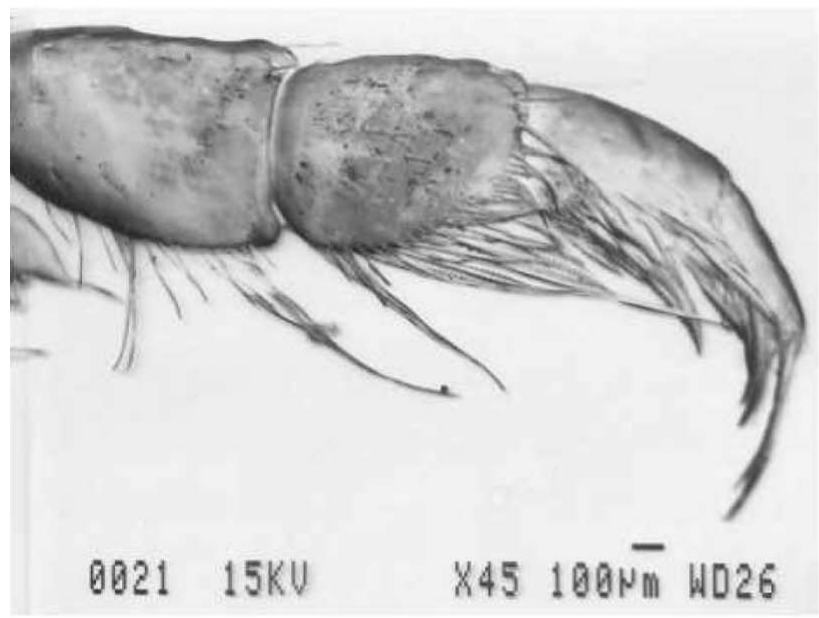

Fig. 14. Second, third, fourth and fifth segment of the third maxilliped in $12 \mathrm{~mm}$ P. leniusculus.

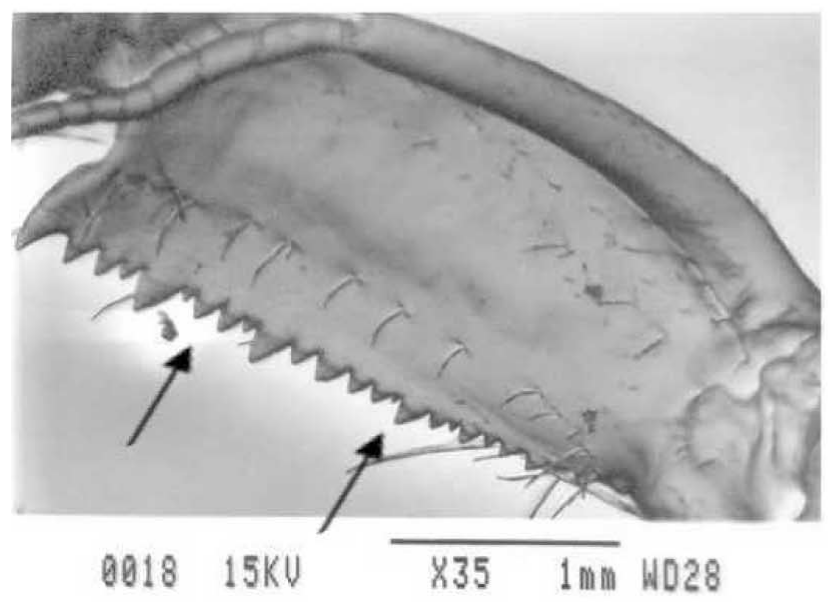

Fig. 15. First segment (crista dentata) of the third maxilliped in 12 $\mathrm{mm}$ P. leniusculus.

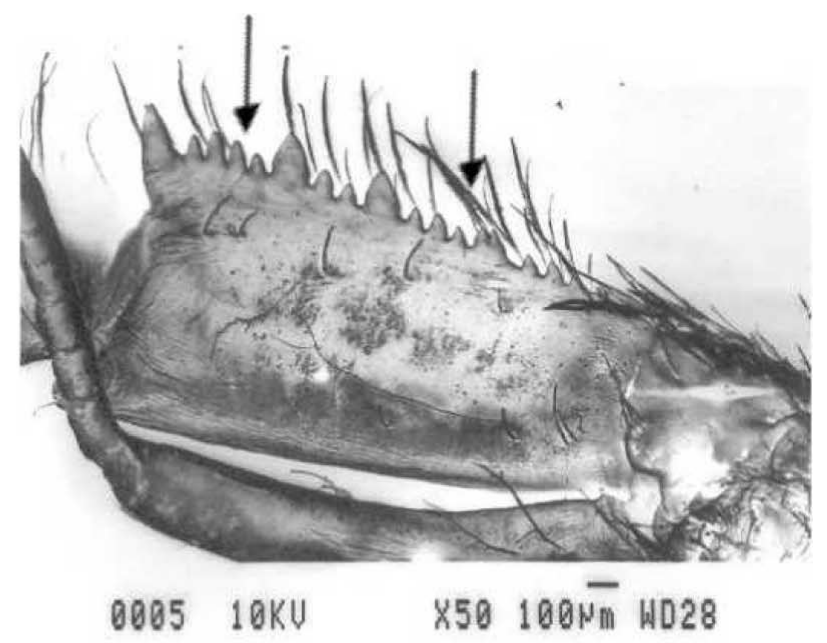

Fig. 16.First segment (crista dentata) of the third maxilliped in 12 $\mathrm{mm}$ A. leptodactylus.

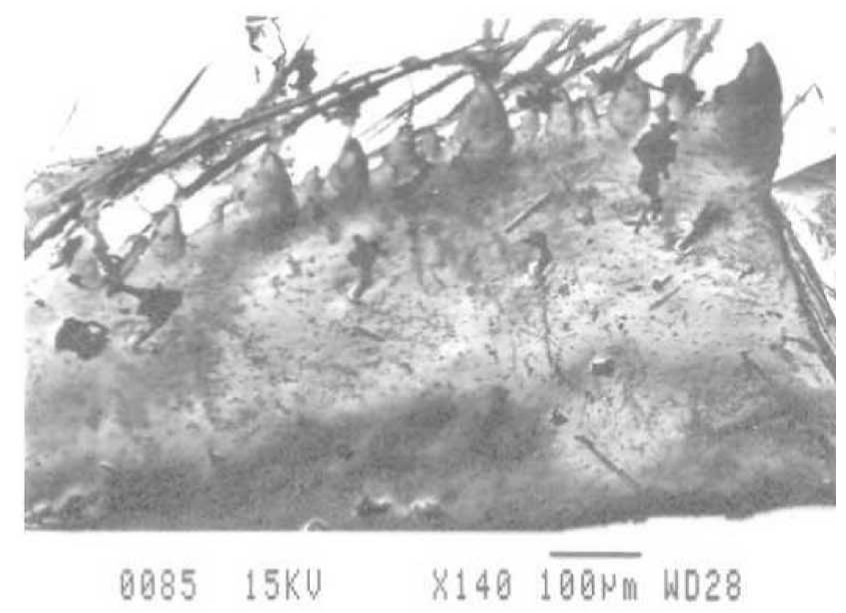

Fig. 17. First segment of the third maxilliped in stage $3 P$. leniusculus.

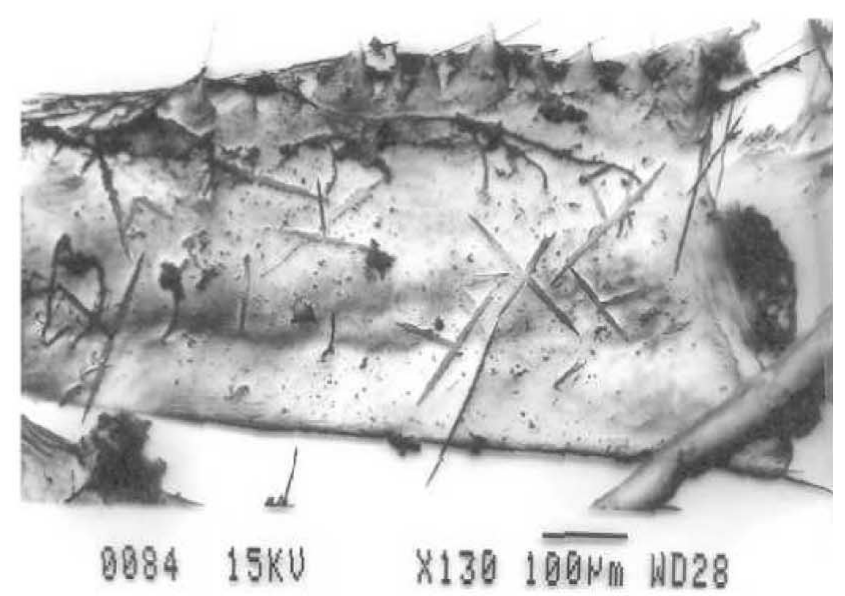

Fig. 18. First segment of the third maxilliped in stage $3 \mathrm{~A}$. leptodactylus. 


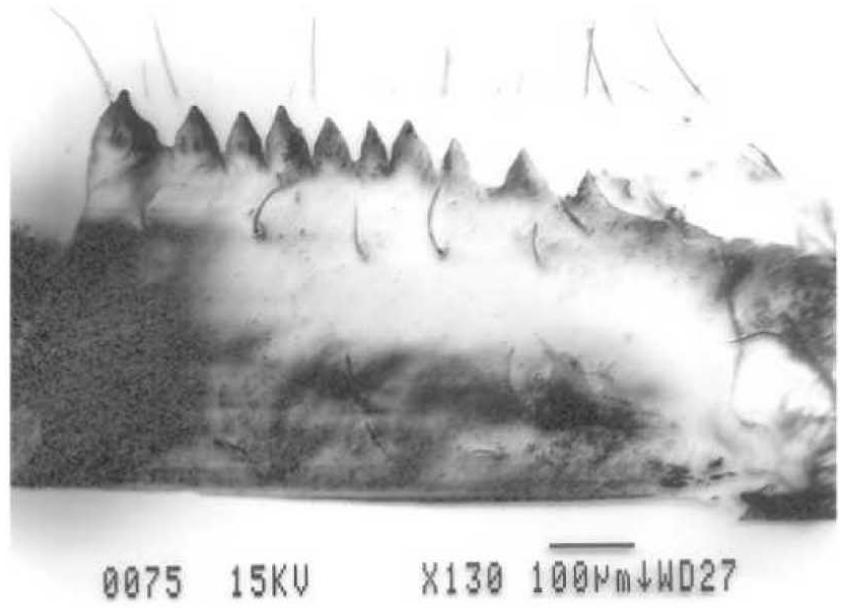

Fig. 19. First segment of the third maxilliped in stage $2 P$. leniusculus.

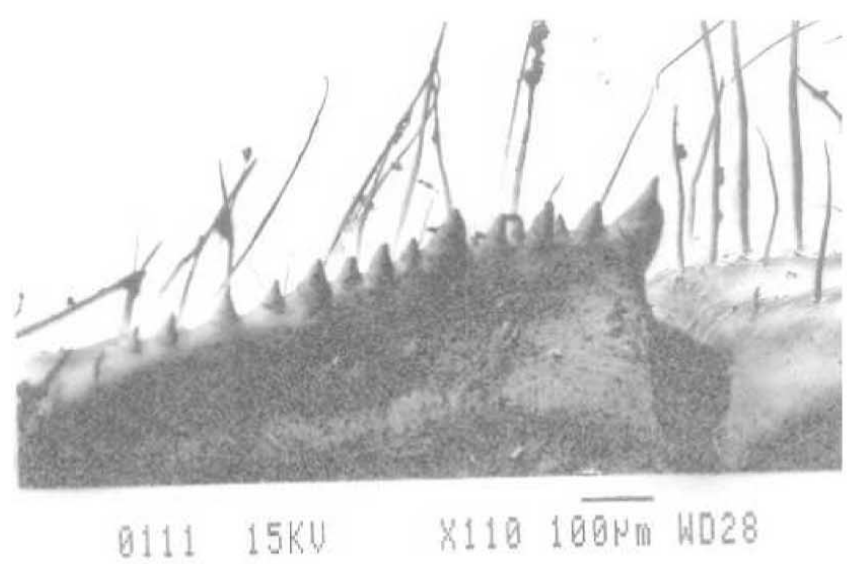

Fig. 20. First segment of the third maxilliped in stage $2 \mathrm{~A}$. leptodactylus.

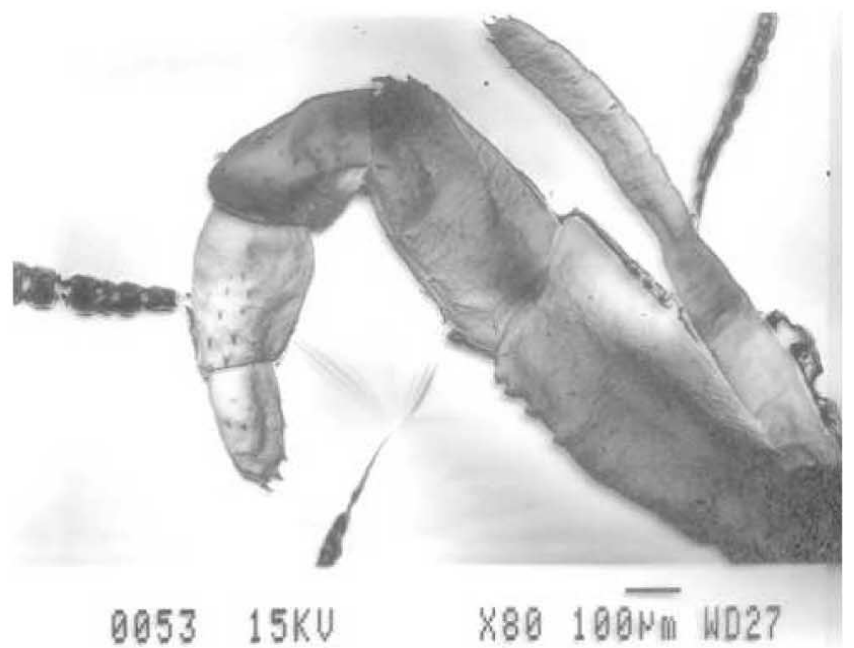

Fig. 21. Third maxilliped of stage 1 P. leniusculus.

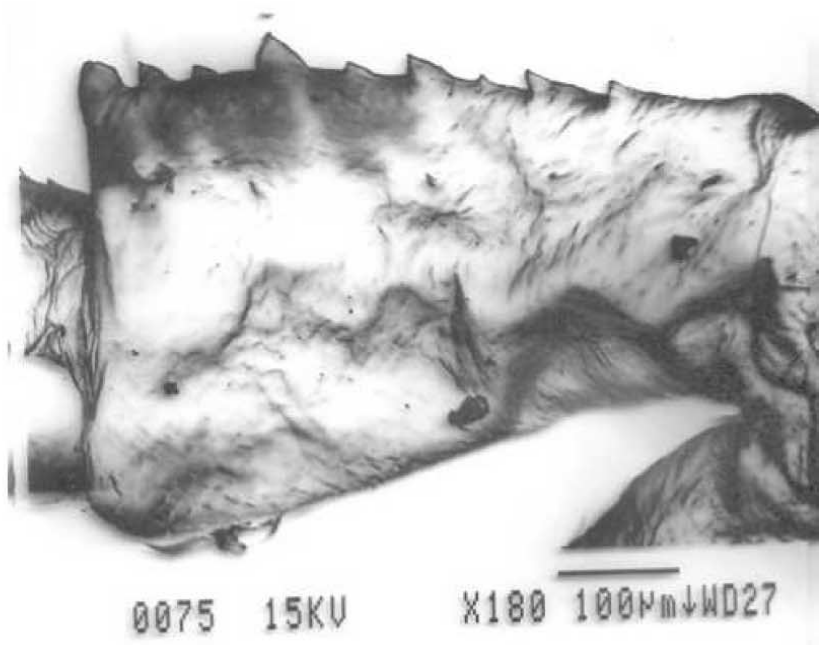

Fig. 22. First segment of the third maxilliped in stage $1 \mathrm{~A}$. leptodactylus.

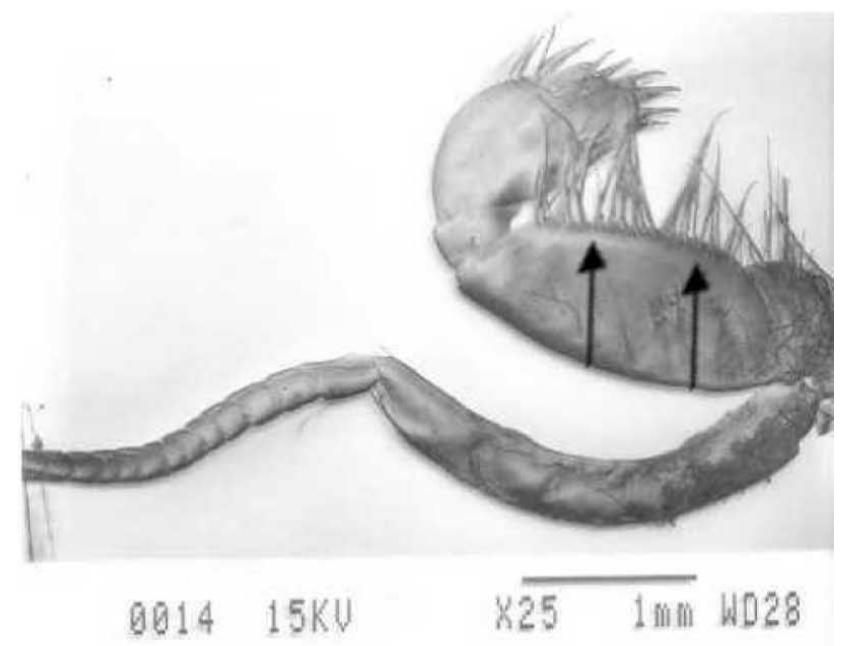

Fig. 23. Second maxilliped of $12 \mathrm{~mm}$ (CL) P. leniusculus.

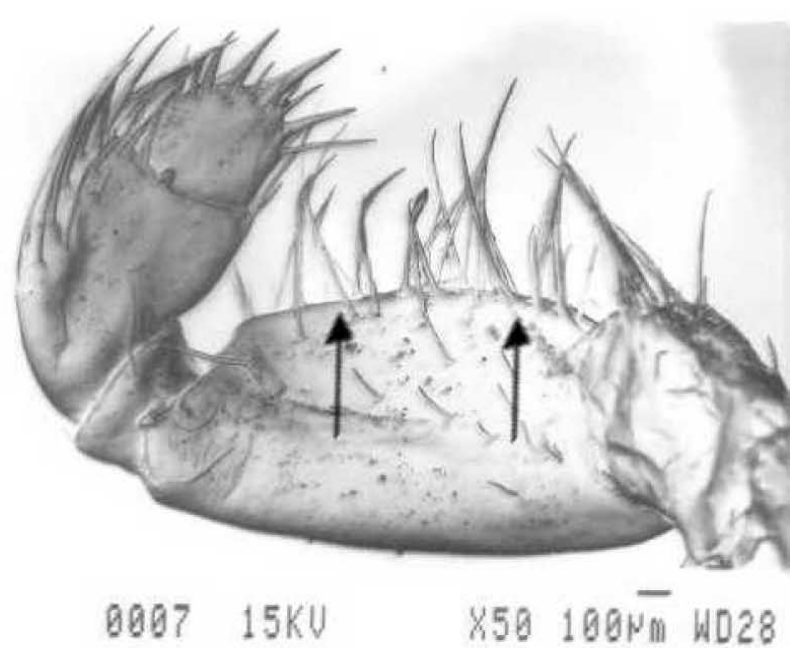

Fig. 24. Second maxilliped of $12 \mathrm{~mm}$ (CL) A. leptodactylus. 
HARLIOGLU, M. M. A scanning electron microscopic study on the appendage morphology of Astacus leptodactylus (Eschscholtz, 1823) and Pacifastacus leniusculus (Dana, 1852) (Crustacea: Decapoda: Astacoidea). Int. J. Morphol., 26(4):1035-1051, 2008.
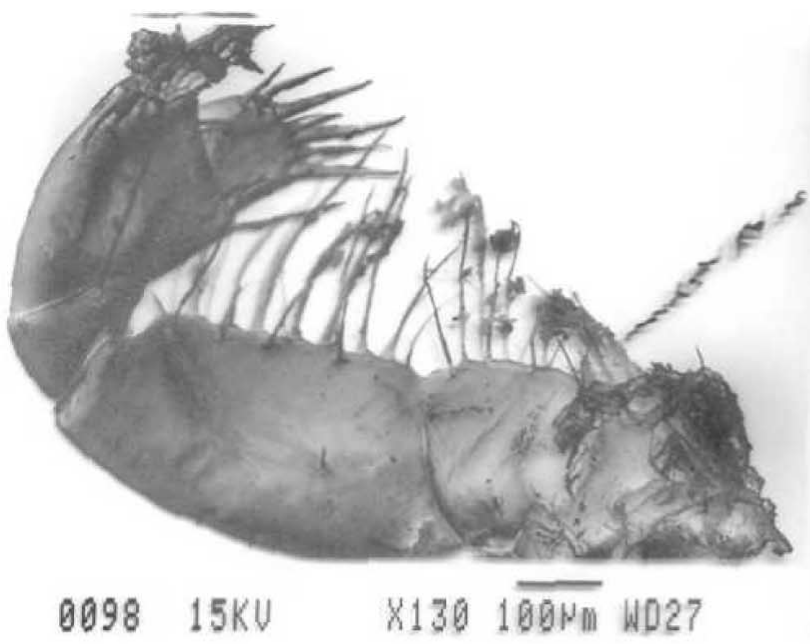

Fig. 25. Second maxilliped of stage 3 P. leniusculus.

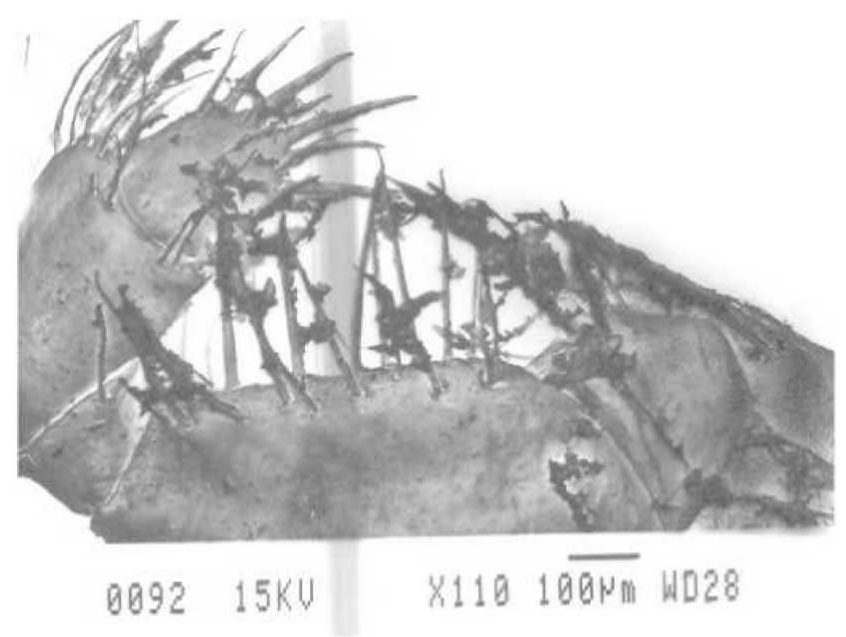

Fig. 26. Second maxilliped of stage 3 A. leptodactylus.

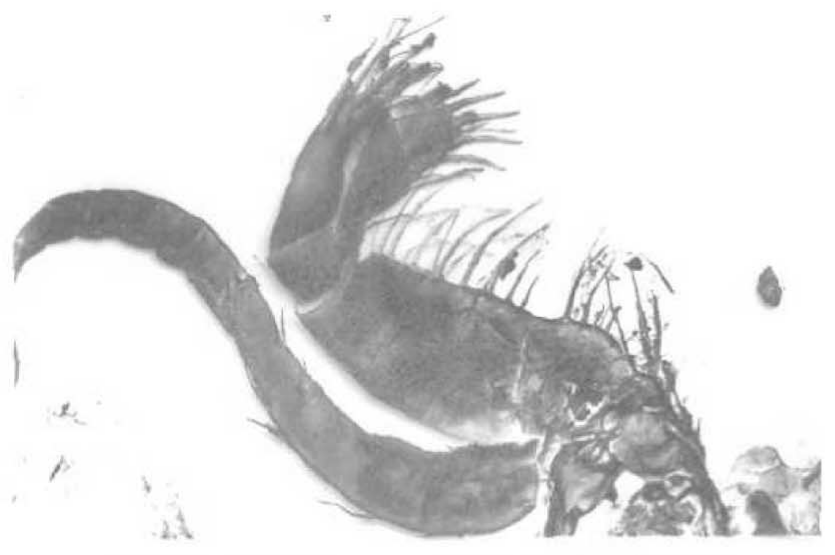

0012 10KV

X85 $100 \overline{\mathrm{Nm}}$ WD29

Fig. 27. Second maxilliped of stage 2 P. leniusculus.

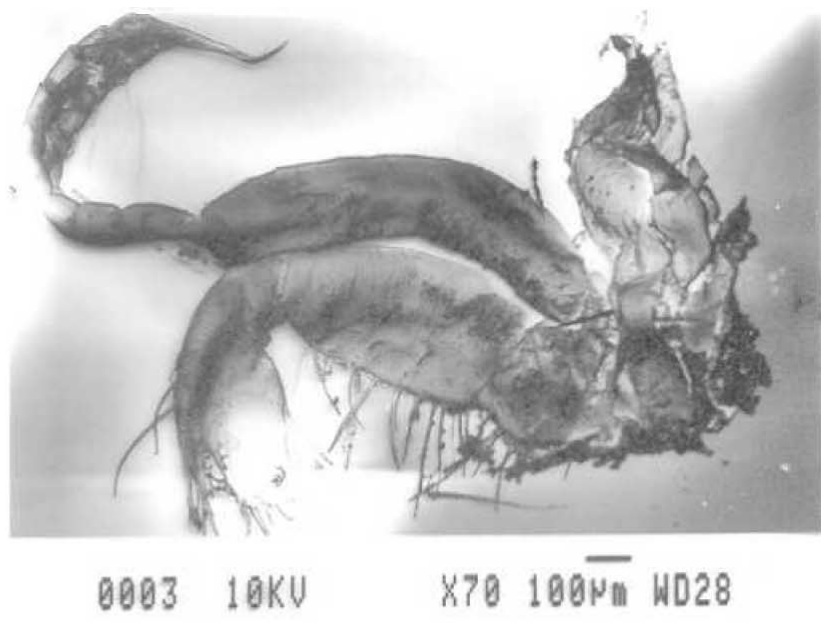

Fig. 28. Second maxilliped of stage 2 A. leptodactylus.

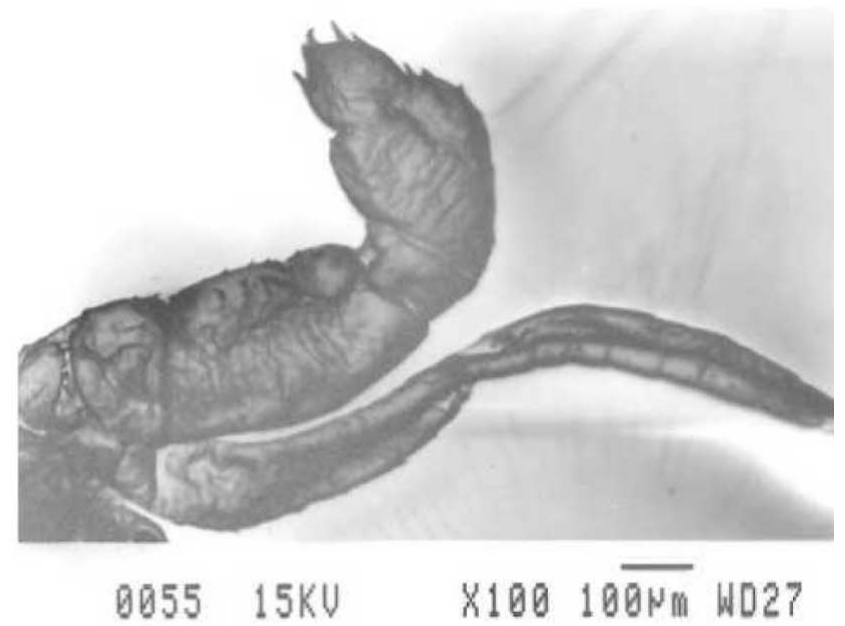

Fig. 29. Second maxilliped of stage 1 P. leniusculus

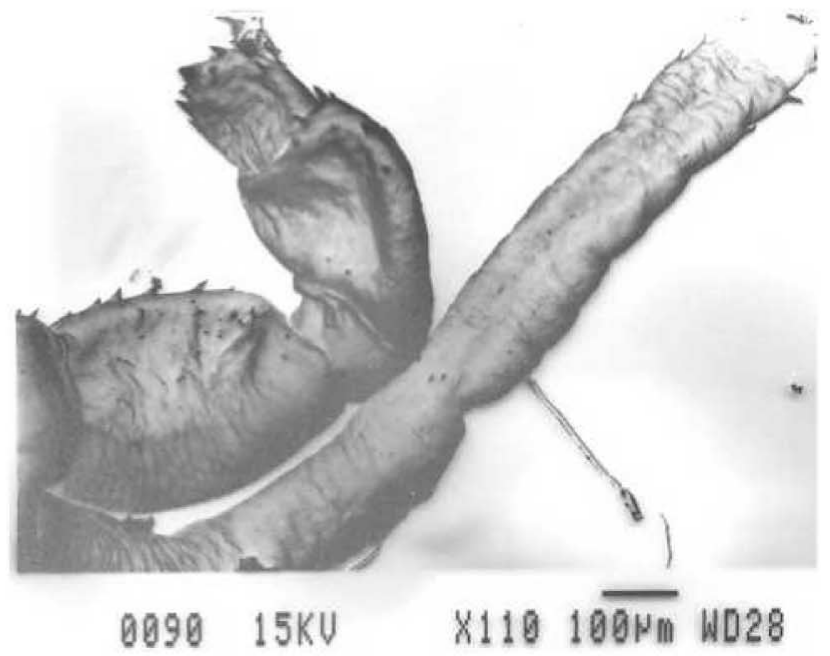

Fig. 30. Second maxilliped of stage 1 A. leptodactylus 
HARLIOGLU, M. M. A scanning electron microscopic study on the appendage morphology of Astacus leptodactylus (Eschscholtz, 1823) and Pacifastacus leniusculus (Dana, 1852) (Crustacea: Decapoda: Astacoidea). Int. J. Morphol., 26(4):1035-1051, 2008.

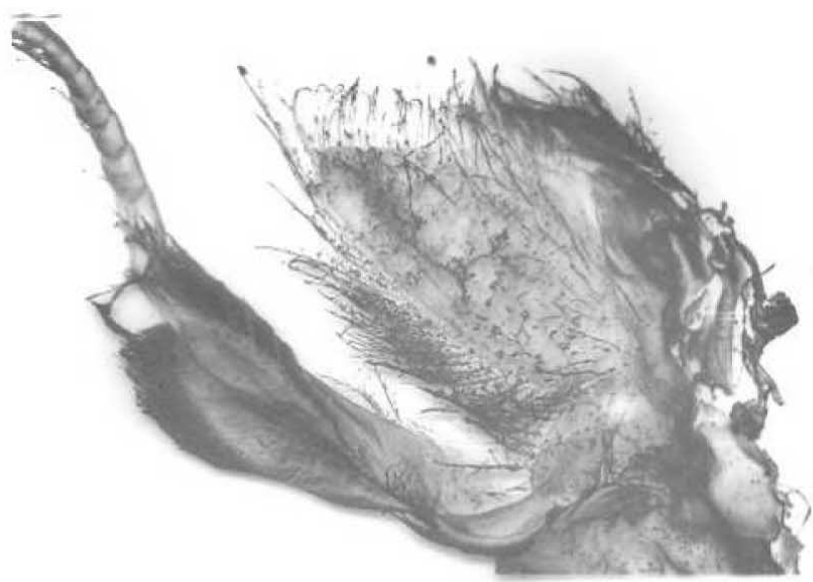

0064 15KU X27 1mili WD27

Fig. 31. First maxilliped of $12 \mathrm{~mm}(\mathrm{CL})$ P. leniusculus.

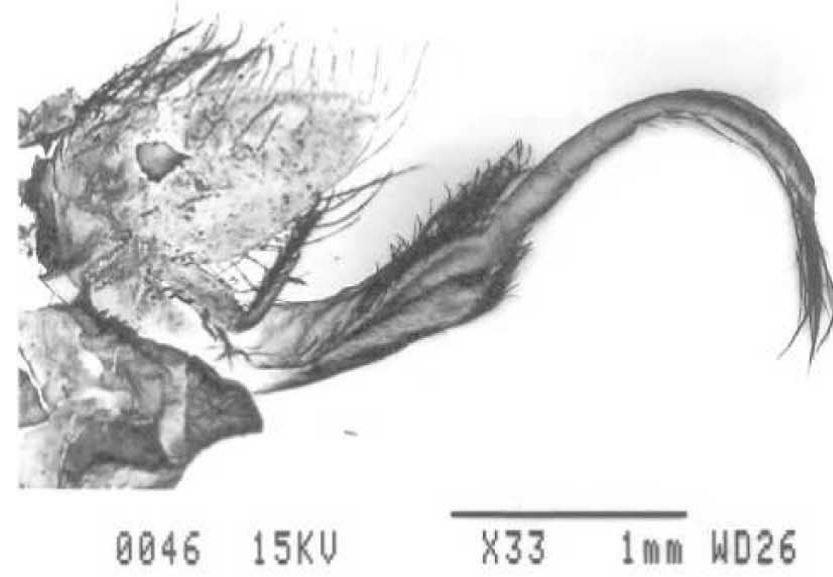

Fig. 32. First maxilliped of $12 \mathrm{~mm}(\mathrm{CL})$ A. leptodactylus.

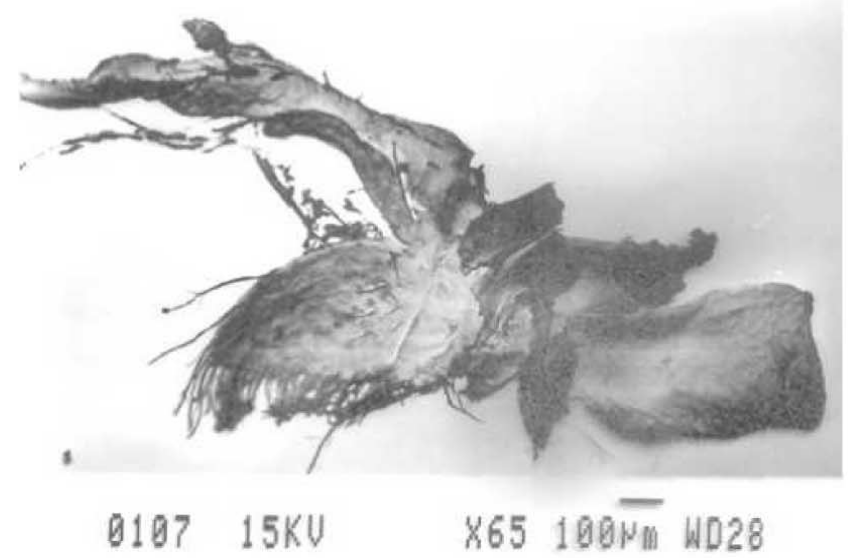

Fig. 33. First maxilliped of stage 3 P. leniusculus.

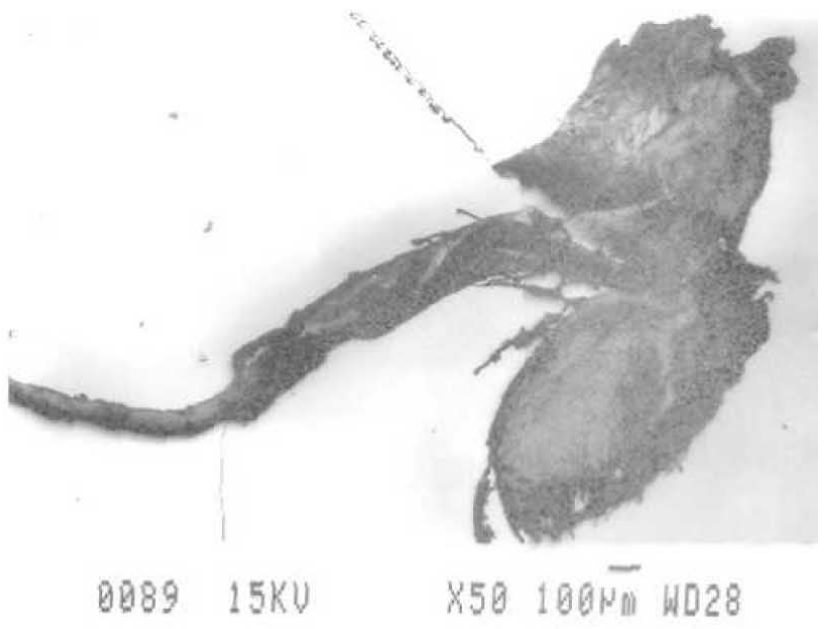

Fig. 34. First maxilliped of stage 3 A. leptodactylus.

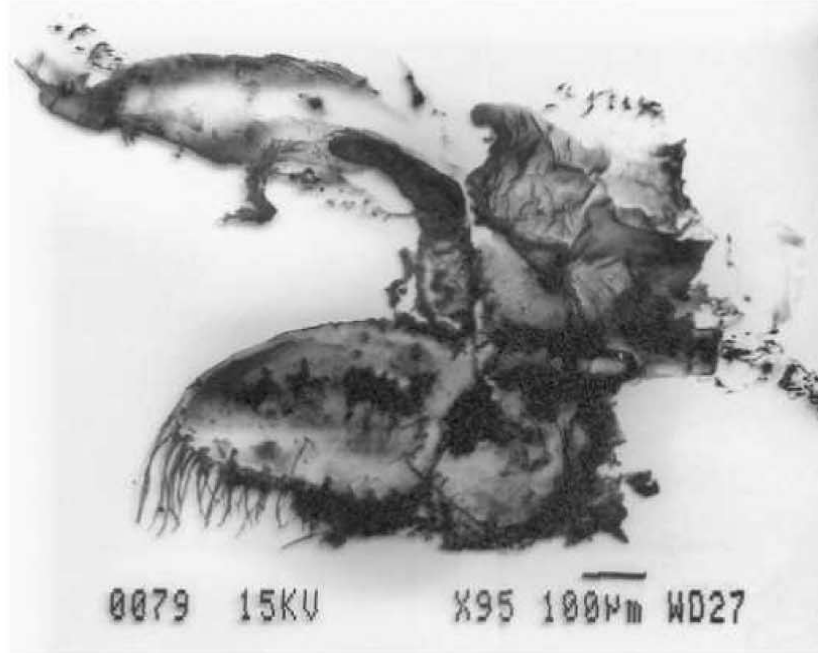

Fig. 35. First maxilliped of stage 2 P. leniusculus.

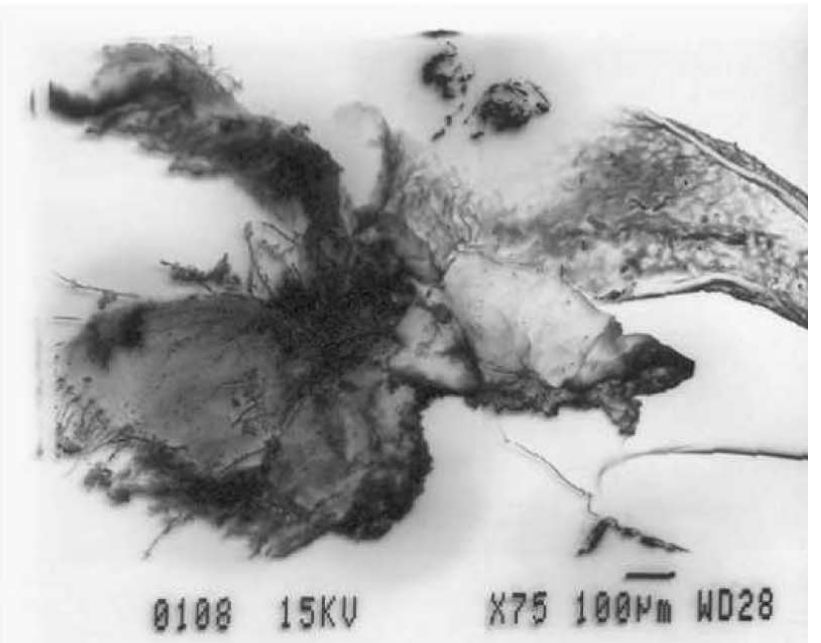

Fig. 36. First maxilliped of stage 2 A. leptodactylus. 


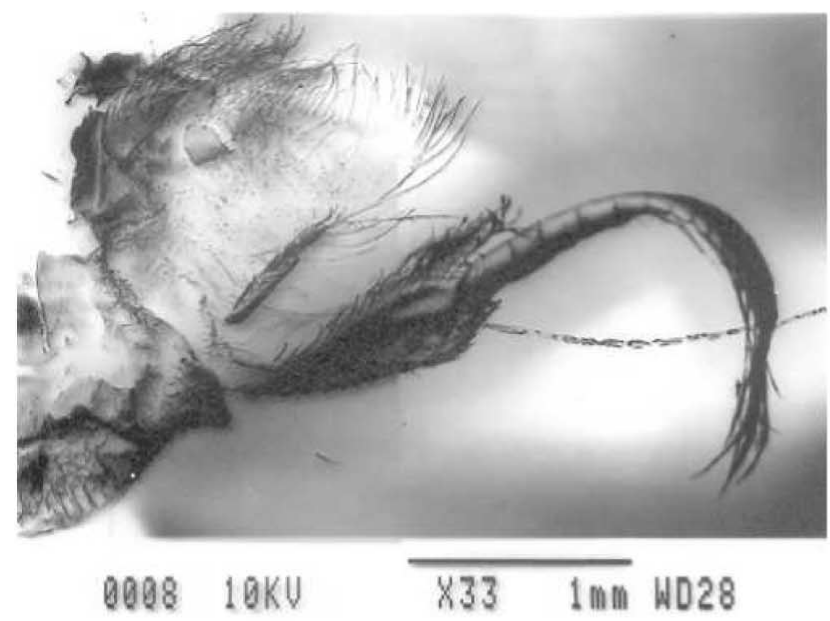

Fig. 37. First maxilliped of stage 1 P. leniusculus.

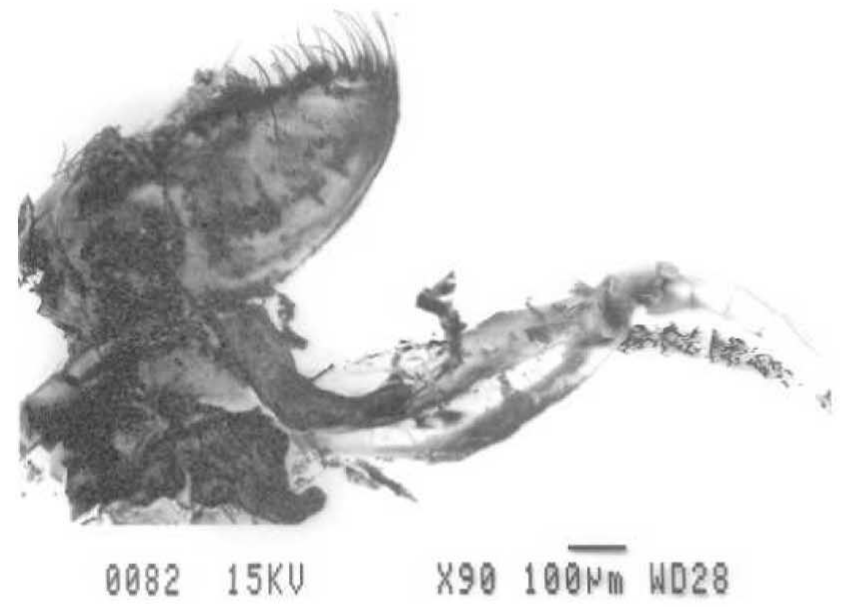

Fig. 38. First maxilliped of stage 1 A. leptodactylus.

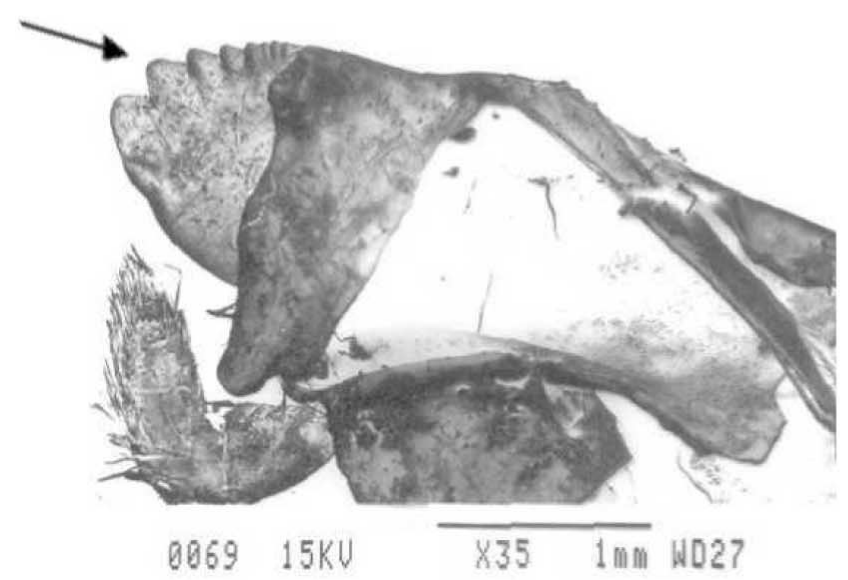

Fig. 39. Mandible of $12 \mathrm{~mm}$ (CL) P. leniusculus.

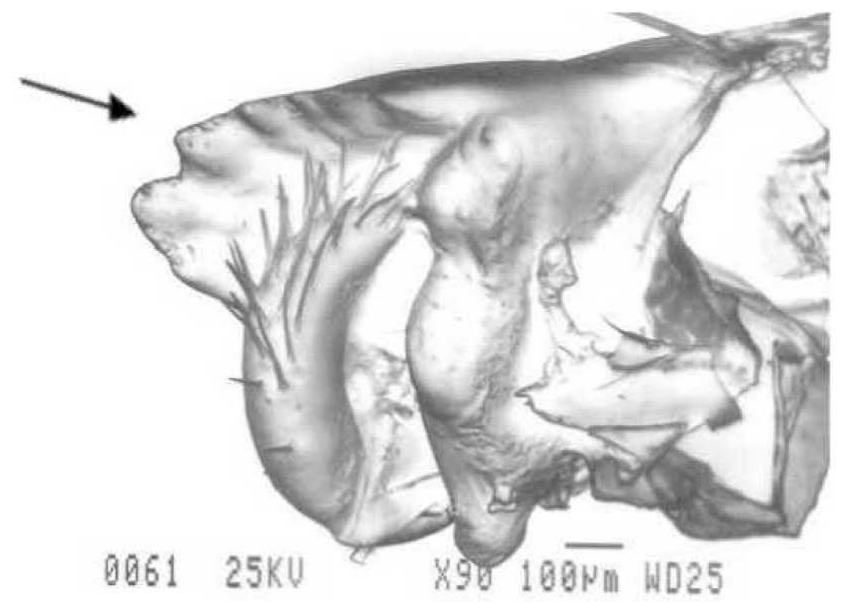

Fig. 40. Mandible of $12 \mathrm{~mm}$ (CL) A. leptodactylus.

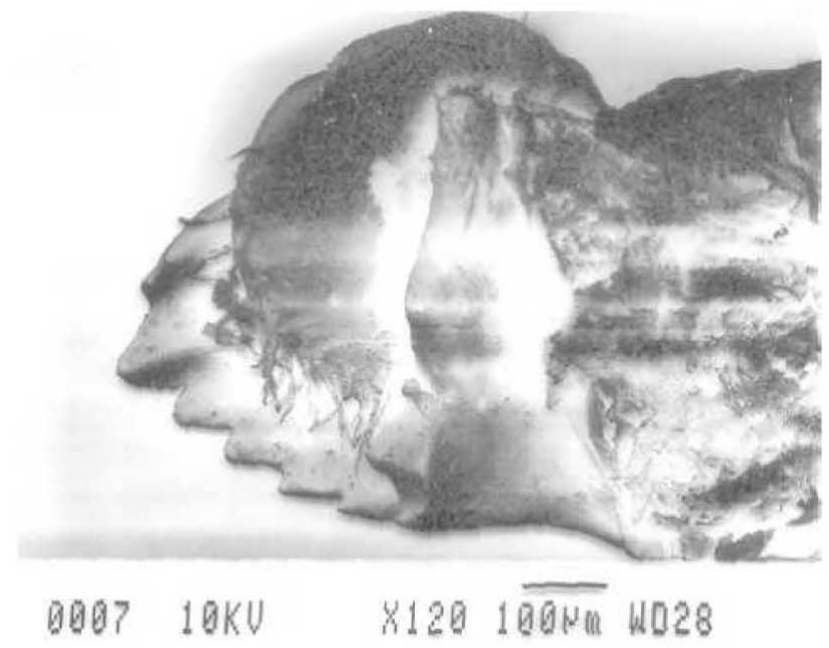

Fig. 41. Mandible of stage 3 P. leniusculus.

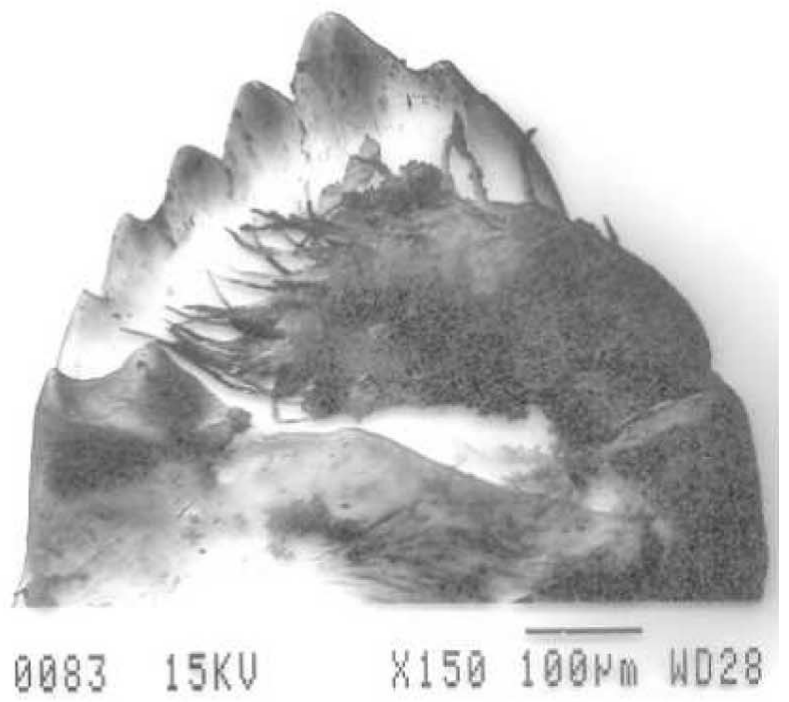

Fig. 42. Mandible of stage 3 A. leptodactylus. 


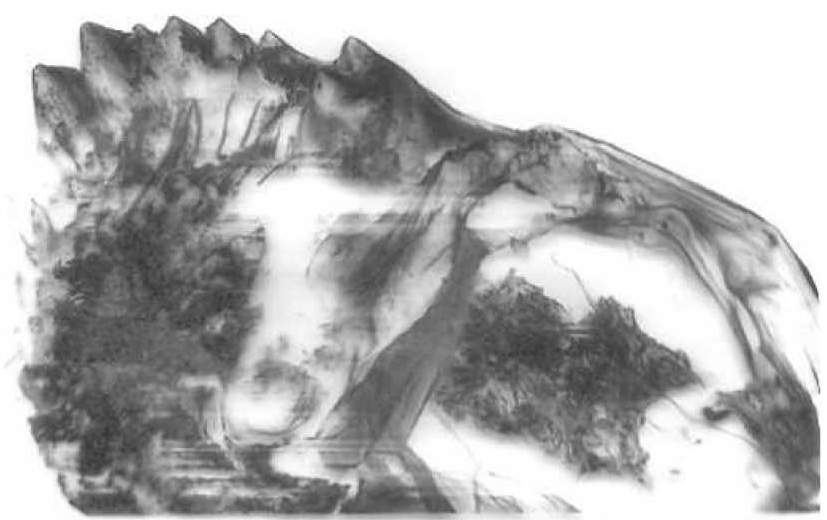

$0077 \quad 15 \mathrm{KU}$

\section{$X 14010 \overline{100 \%} \downarrow W 027$}

Fig. 43. Mandible of stage 2 P. leniusculus.

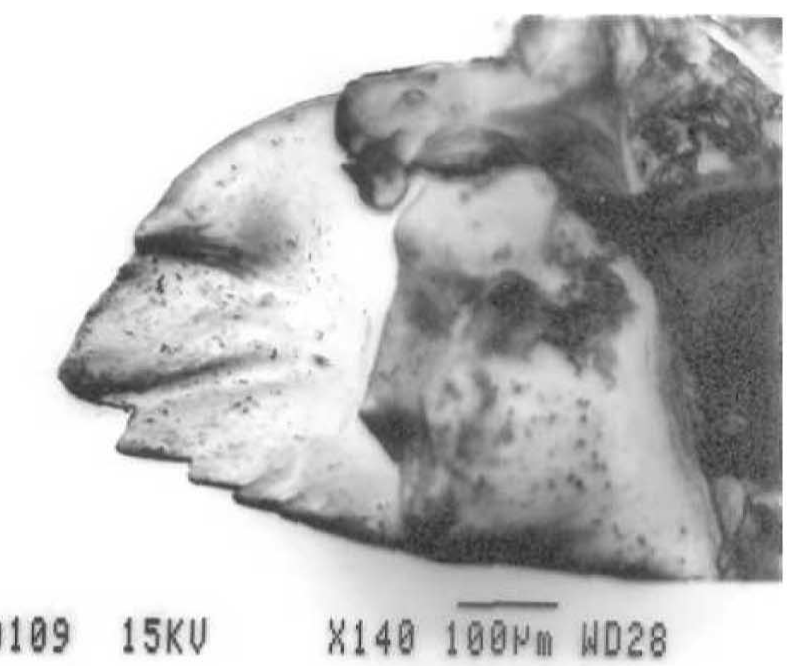

Fig. 44. Mandible of stage 2 A. leptodactylus.

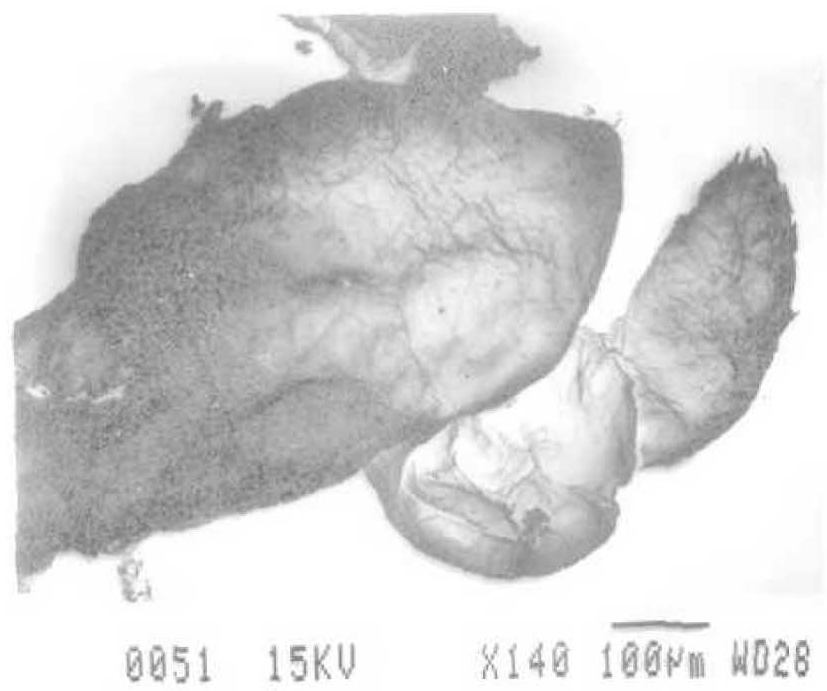

Fig. 45. Mandible of stage 1 P. leniusculus.

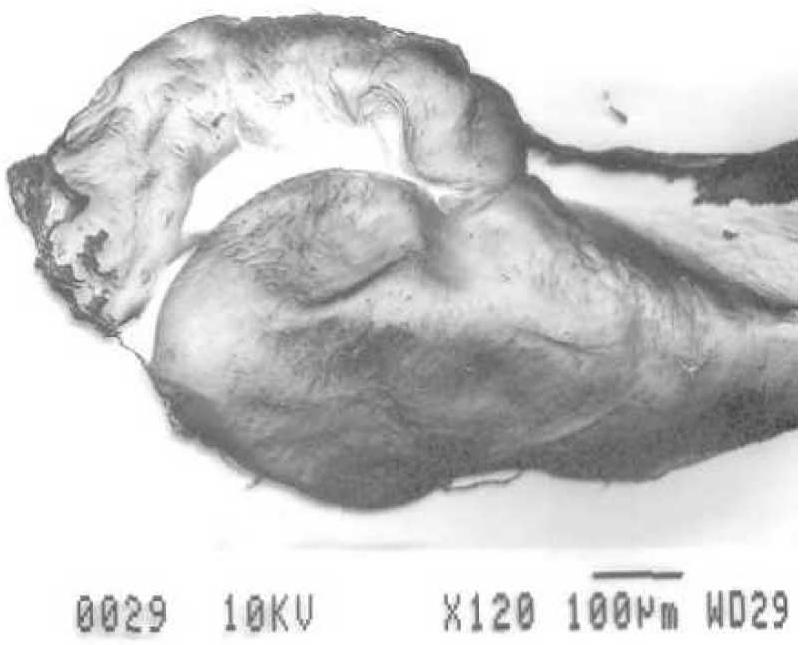

Fig. 46. Mandible of stage 1 A. leptodactylus.

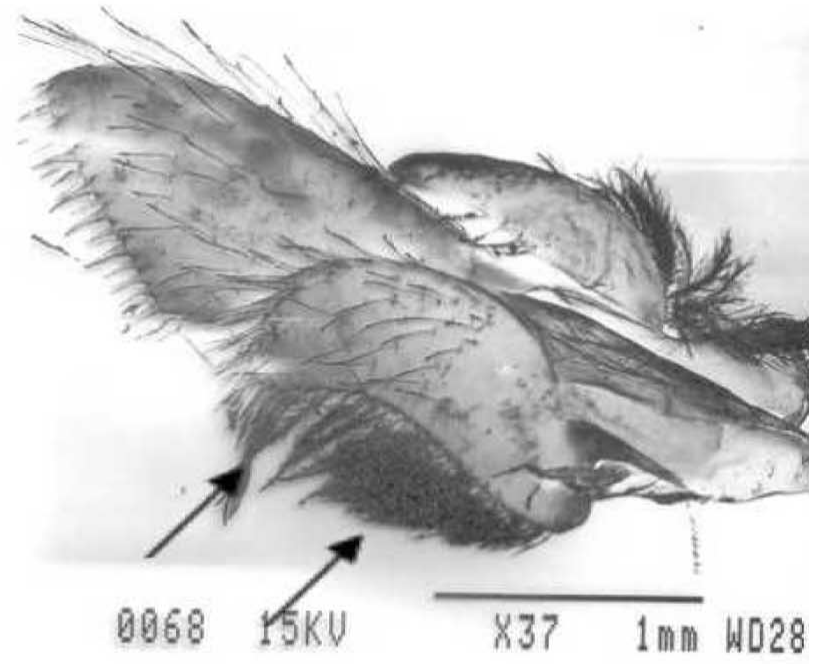

Fig. 47. Maxillule of $12 \mathrm{~mm}$ (CL) P. leniusculus.

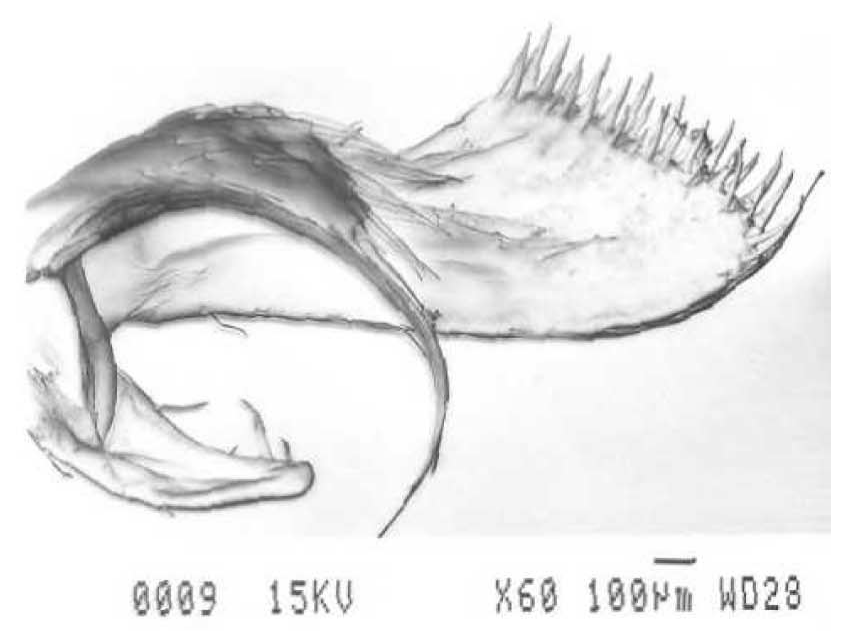

Fig. 48. Maxillule of $12 \mathrm{~mm}$ (CL) A. leptodactylus. 


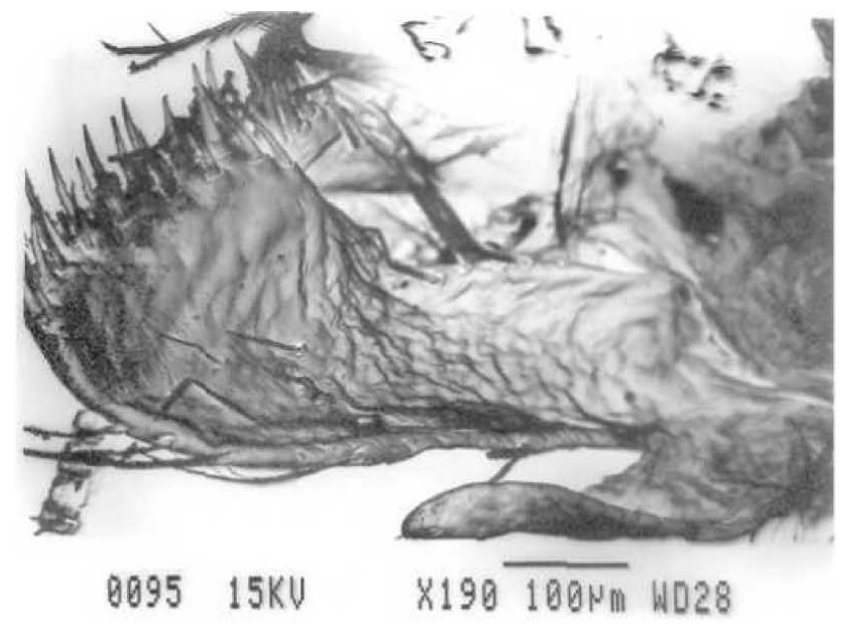

Fig. 49. Maxillule of stage 3 P. leniusculus.

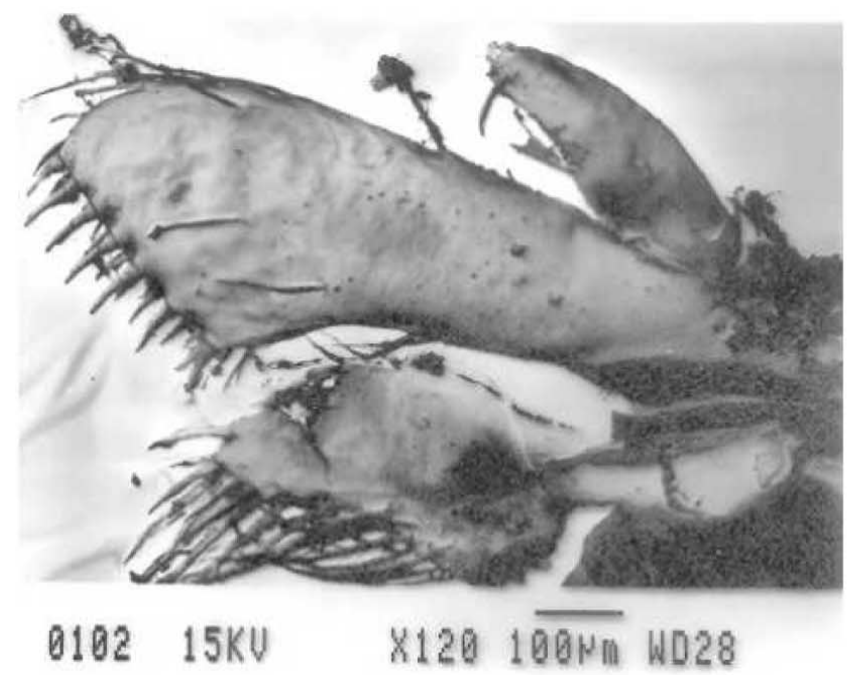

Fig. 50. Maxillule of stage 3 A. leptodactylus.

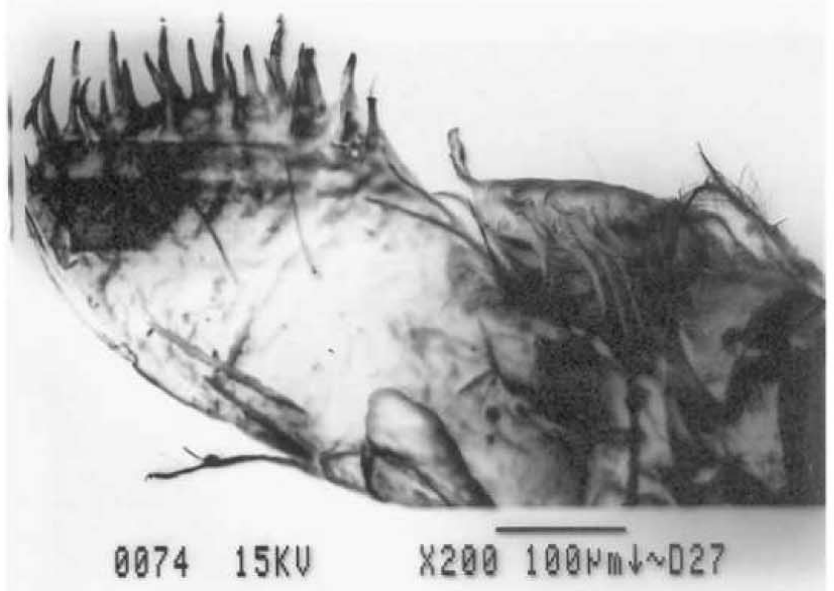

Fig. 51. Maxillule of stage 2 P. leniusculus.

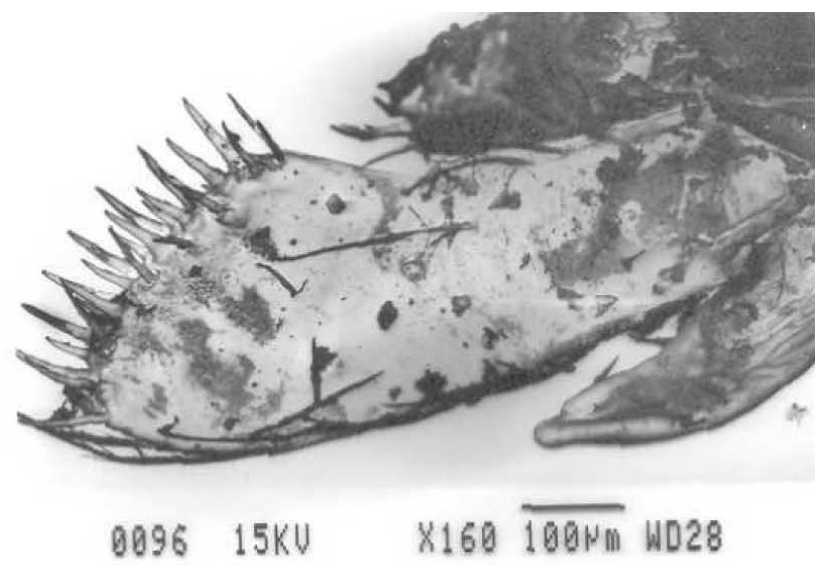

Fig. 52. Maxillule of stage 2 A. leptodactylus.

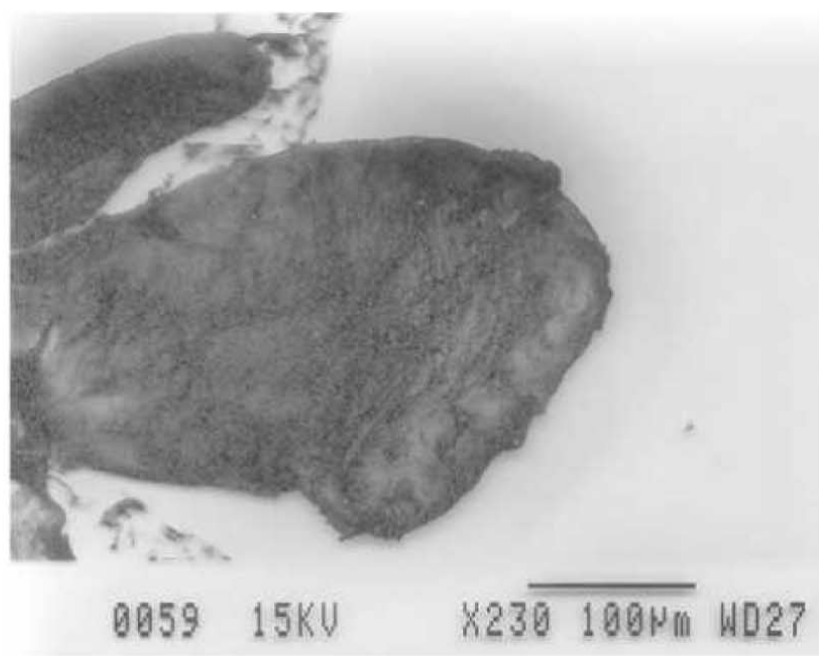

Fig. 53. Maxillule of stage 1 P. leniusculus.

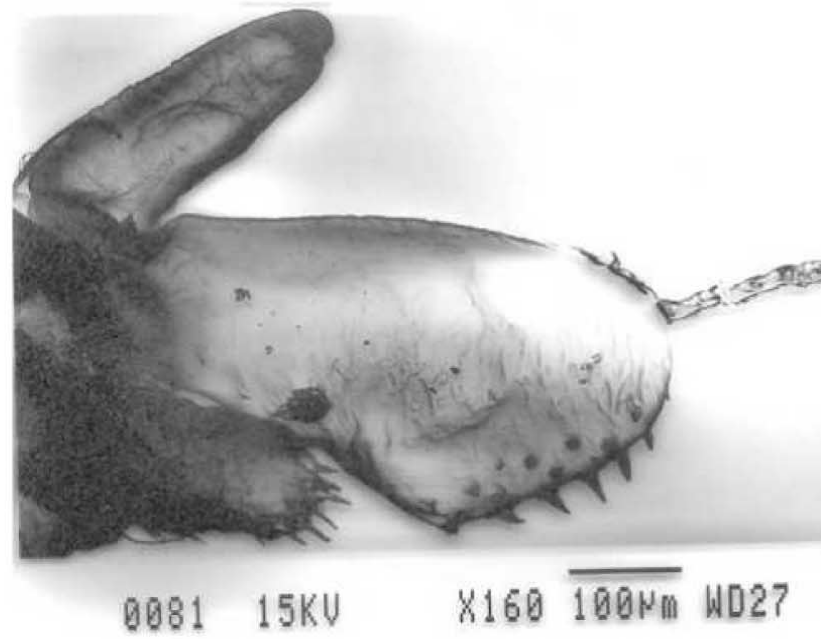

Fig. 54. Maxillule of stage 1 A. leptodactylus. 
HARLIOGLU, M. M. A scanning electron microscopic study on the appendage morphology of Astacus leptodactylus (Eschscholtz, 1823) and Pacifastacus leniusculus (Dana, 1852) (Crustacea: Decapoda: Astacoidea). Int. J. Morphol., 26(4):1035-1051, 2008.

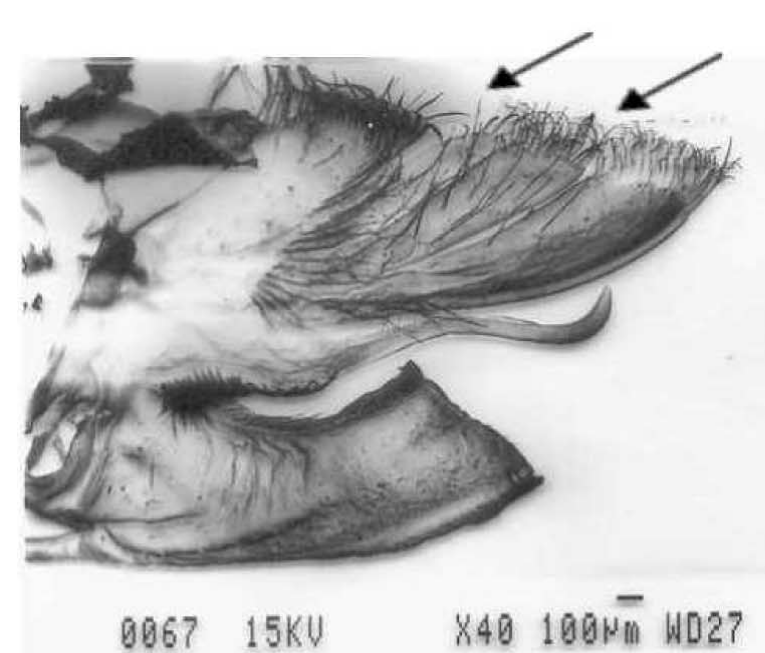

Fig. 55. Maxilla of $12 \mathrm{~mm}$ (CL) P. leniusculus.

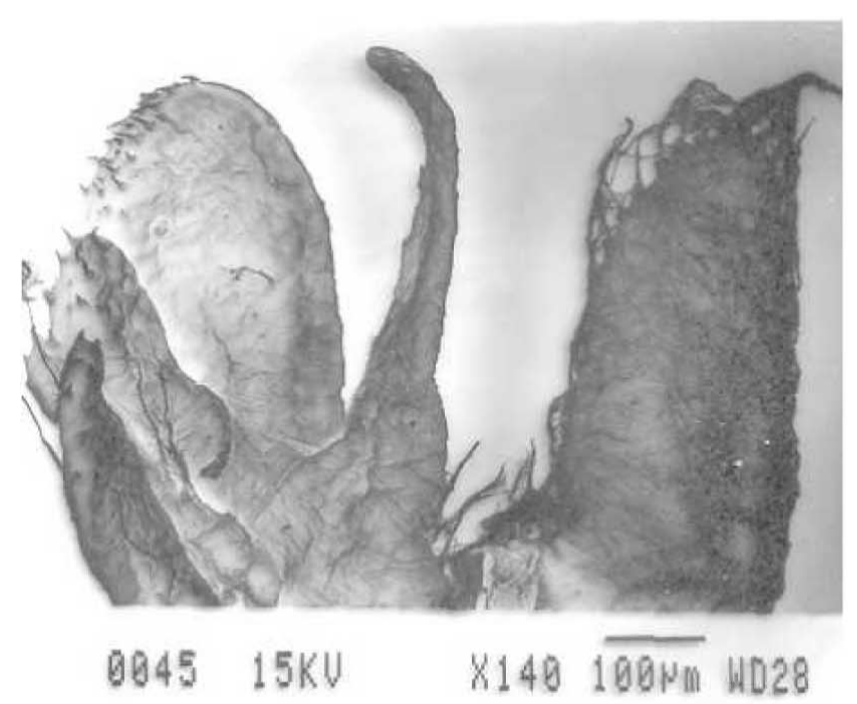

Fig. 56. Maxilla of $12 \mathrm{~mm}$ (CL) A. leptodactylus.

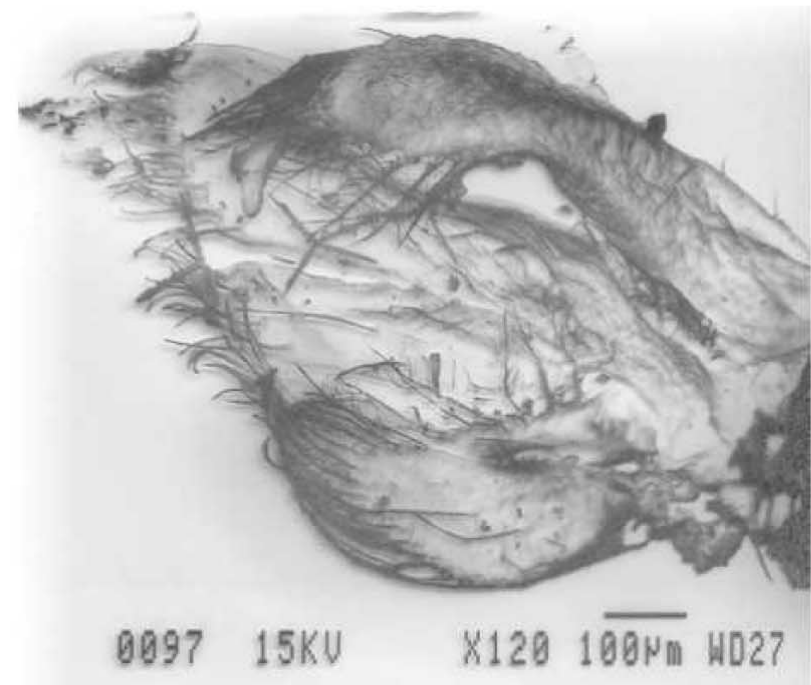

Fig. 57. Maxilla of stage 3 P. leniusculus.

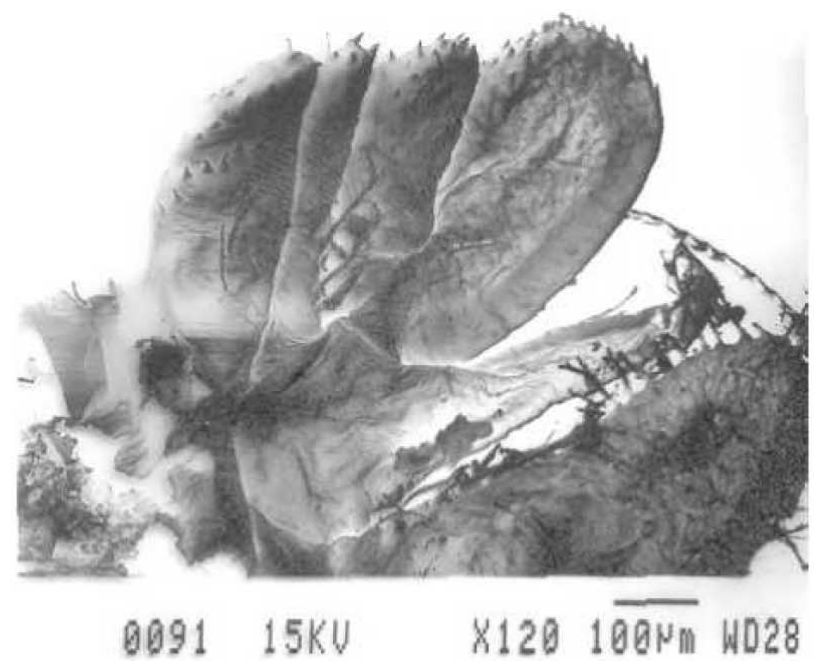

Fig. 58. Maxilla of stage 3 A. leptodactylus.

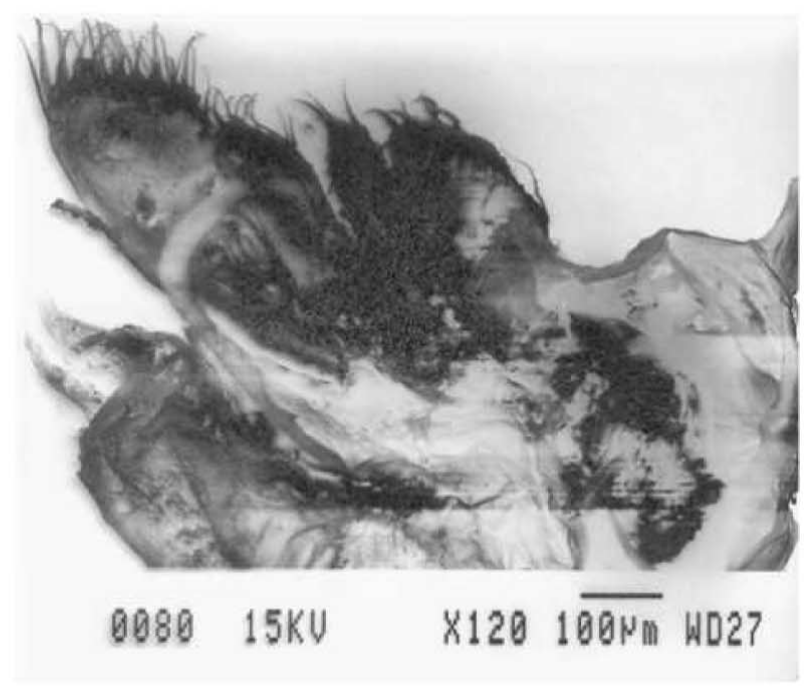

Fig. 59. Maxilla of stage 2 P. leniusculus.

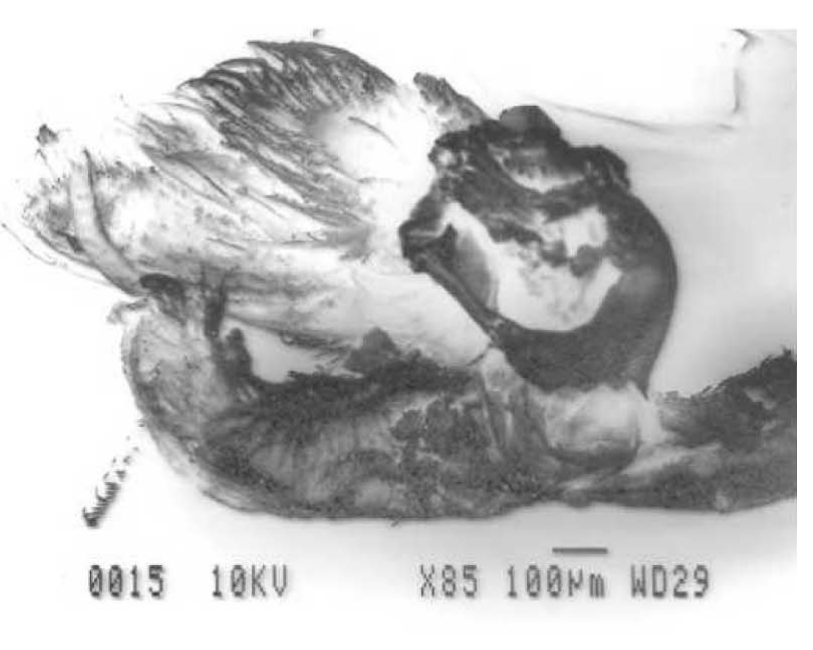

Fig. 60. Maxilla of stage 2 A. leptodactylus. 
between the stages (stage 1 , stage 2 , stage 3 ) and $12 \mathrm{~mm}$ (CL) juveniles. Differences between the stages were given in Figs. 17-22 for the third maxilliped, in Figs. 25-30 for the second maxilliped, in Figs. 33-38 for the first maxilliped, in Figs. 41-46 for the mandible, in Figs. 49-54 for the maxillae and in Figs. 57-60 for the maxilla of the two species.

It was observed that differences mainly occur in the length and abundance of setea on the feeding appendages, and in the number and dimension of teeth on the mandibles and the crista dentata of the third maxillipeds.

The increase in the number and dimension of teeth on the mandible of $P$. leniusculus as the crayfish moults are shown in Figs. 45, 43, 41, 39, and those of A. leptodactylus are given in Figs. 46, 44, 42, 40. Similarly, the increase in the number and dimension of teeth on the crista dentata of $\mathrm{P}$. leniusculus as the crayfish moults are shown in Figs. 21, 19, 17, 15, and those of A. leptodactylus in Figs. 22, 20, 18, 16.

Presence of setae were found in the maxillipeds (first, second and third), mandible, maxillule, and maxilla of the two species (Figs. 37, 29, 21, 45, 53 for P. leniusculus, and Figs. 38, 30, 22, 46, 54 for A. leptodactylus respectively). Although setae were also seen in the maxilla of stage $1 P$. leniusculus and A. leptodactylus, because of too much charging, they are not shown.

\section{DISCUSSION}

Pacificastacus leniusculus and A. leptodactylus are assigned to the Astacidae which contains only three genera: Astacus, Austropotamobius and Pacifastacus (Hobbs, 1988). Development in P. leniusculus and A. leptodactylus is epimorphic, i.e., it takes place within the egg, and what hatches out is similar to an adult (Holdich, 1992; Harlioglu, 2002). Consequently, P. leniusculus and A. leptodactylus are similar in their morphology and share many common features (Hobbs, 1988). Indeed, in the present study, similarities were observed in the morphology of appendages and mouthparts and in their setal armature between P. leniusculus and $A$. leptodactylus. For example, the shape of the rostra in $P$. leniusculus and A. leptodactylus is similar, and both species have two postorbital spines.

However, important differences in the morphology of appendages and mouthparts were found between $P$. leniusculus and A. leptodactylus. In addition, changes in the morphology in the feeding apparatus and appendages between the developmental stages of the two species were observed. For instance, the observations showed that $A$. leptodactylus has a prominent tubercle on the shoulder of carapace, which is absent in P. leniusculus. According to Harlioglu (1996) this prominent tubercle is a suitable character distinguish stage 2 juveniles of the two species under the light microscope. This spine is also present in Austropotamobius pallipes (but not in stage 2 of $A$. pallipes) (NRA, 1994).

It is well known that stage 1 juveniles are not active feeders (Thomas, 1970). Although stage 1 juveniles feed on the yolk, setae were found on all the maxillipeds (first, second and third), mandible, maxillule, and maxilla of the two species. Moreover, the differences in the setal armature of mouthparts as observed in the present study may lead to differences in the feeding behavior between P. leniusculus and A. leptodactylus. It seems that when the juveniles are feed the same diet $P$. leniusculus might have an advantage over A. leptodactylus because of its long and abundant setae on the second maxilliped, more teeth on the mandibles and crista dentata, and form of dactylus and propodus of the chelipeds. Similarly, from the observations described above it is clear that the increase in the number and dimension of teeth on the mandible and crista dentata of juveniles may enable them to cope with different types of food as they get older.

Food preference of crayfish has been subjected to several studies. The preference of two sizes of juvenile and an adult $P$. leniusculus in the consumption of aquatic weeds has been reported by Warner \& Green. This preference is Spirogyra sp., Ceratophyllum demersum, Elodea canadensis or Groenlandia densa respectively for all three crayfish size groups. Warner et al. (1995) have also found that when different sizes of snails are offerred although larger $P$. leniusculus (55 and $61 \mathrm{~mm} \mathrm{CL}$ ) show no prefence, smaller P. leniusculus (16-44 mm CL) prefer to eat some sizes of snails more frequently than larger and smaller sizes, and smaller or larger snails are not eaten by the smaller $P$. leniusculus until prey abundance declines.

Momot (1995) is of the opinion that many crayfish species are primarily carnivorous. He bases this on the fact that they need animal protein to maintain their lifestyle and relatively fast growth rates in the summer months. He maintains that plant food is taken in secondarily or when animal food is not readily available. Indeed Guan found a high proportion of animal food items in the guts of $P$. leniusculus in his study of a wild population. Others have shown, however, that this species is effective at clearing nuisance weeds in water bodies (Blake \& Laurent, 1982). It seems likely therefore that crayfish need to possess an array of setal types to cope with all eventualities. As P. leniusculus and A. leptodactylus are closely related and can occupy si- 
milar environments it is not surprising that the setal armature of their appendages is comparable.

Harlioglu (2000) stated that the incisor ridge modification of mandibles may cause the difference in the food choice of different size crayfish, because different ridge structures of mandible may select different type of food. Harlioglu (2003) also stated that the differences in the crista dentate structure and different tooth number of the ischium of third maxilliped, as observed in the present study, cause a different cutting edge and variations in the food choice of crayfish.

Differences in mouthparts have also been found in penaeid prawns which fed on a wide range of food. It was observed that eleven species show food preferences out of 31 species. Moreover, food preferences were observed in the different stages of the same species due to the fact that they possess different mouthpart structures and setal types in their ontogeny (Hindley \& Alexander).

In conclusion, important differences occur in the morphology of appendages and mouthparts between $P$. leniusculus and A. leptodactylus, and in the developmental stages of the species. The morphological differences in mouthparts may cause a difference in the feeding behavior and food choice of the species.

\section{ACKNOWLEDGMENT}

Many thanks are dedicated to my supervisor, Dr. David Holdich for his support and encourament during the course of this study. Thanks are also dedicated to Tim Smith for helping me learn to use the scanning electron microscope, to Brain Case for developing the photographs.

HARLIOGLU, M. M. Estudio en microscópio electrónico de barrido sobre el apéndice morfológico del Astacus leptodactylus (Eschscholtz, 1823) y Pacifastacus leniusculus (Dana, 1852) (Crustacea: Decapoda: Astacoidea). Int. J. Morphol., 26(4):1038-1051, 2008.

RESUMEN: Este estudio compara la morfología del rostro, pereiópodos 1,2,4 y piezas bucales de los Astacus leptodactylus jóvenes con los de Pacifastacus leniusculus. Se observaron las diferencias en la morfología, en particular, con respecto a las piezas bucales, por ejemplo incluyendo la armadura setal y el número de dientes en la mandíbula. En general, la forma del rostro en las dos especies es similar, tanto cónicas, como en punta, con un par de espinas distalmente. Lateralmente al rostro, A. leptodactylus está bordeada por un fila de setas, que no está tan bien definida en P. leniusculus. Las observaciones también muestran que, además de un aumento en el tamaño, estaban presentes cambios en la morfología en el aparato masticatorio, entre las etapas de desarrollo de las dos especies. Se llegó a la conclusión que ambas especies tienen rostros similares, pero diferentes patrones setales y hay diferencias entre las dos especies en la armadura de piezas bucales como evolución del desarrollo. Por lo tanto, importantes diferencias en la morfología de piezas bucales entre P. leniusculus y A. leptodactylus y en las distintas etapas de la especie podrían causar una diferencia en la conducta de alimentación y opciones de alimentación de la especie.

PALABRAS ClAVE: Apéndices; Astacus; Cangrejos; Piezas bucales; Pacifastacus; Microscopio electrónico de barrido.

\section{REFERENCES}

Alexander, C. G.; Hindley, J. P. R. \& Jones, S. G. Structure and function of the third maxillipeds of the banana prawn Penaeus merguiensis. Mar. Biol., 58:245-9, 1980.

Andrews, E. A. The young of the crayfish Astacus (Pacifastacus leniusculus) and Cambarus (Orconectes limosus). Smithsonian Contributions to Knowledge, XXXV:88, 1907.

Aspan, A. \& Söderhall, K. Purification of prophenoloxidase from crayfish blood cells, and its activation by an endogenous serine proteinase. Insect. Biochem., 21:36373,1991 .

Blake, G. \& Laurent, P. J. Le faucardage par des ecrevisses, resultats preliminaires. Bull. mens. Soc. linn. Lyon, 6:203$8,1982$.

Bouchard, R. W. Morphology of the mandible in holarctic crayfishes (Decapoda: Astacidae and Cambaridae): ecological and phylogenetic implications. Freshwater Crayfish, 3:425-52, 1977.

Brodski, S. Y. On the systematics of palaearctic crayfishes (Crustacea, Astacidae). Freshwater Crayfish, 5:464-70, 1983.

Cherkashina, N. Ya. Distribution and biology of crayfish (Astacidae) along the southeastern coast of the Caspian Sea. Gidrobiology ZH., 6:83-5, 1975. 
HARLIOGLU, M. M. A scanning electron microscopic study on the appendage morphology of Astacus leptodactylus (Eschscholtz, 1823) and Pacifastacus leniusculus (Dana, 1852) (Crustacea: Decapoda: Astacoidea). Int. J. Morphol., 26(4):1035-1051, 2008.

Curra, R. A. A key to genera, species and subspecies of Astacinae (Nephropsidea: Astacidae). Int. Revue ges. Hydrobiol., 52:793-800, 1967.

Dana, J. D. Conspectus Crustaceorum, \&c. Conspectus of the Crustacea of the Exploring Expedition under Captain. C. Wilkes, U.S.N. Proceedings of the Academy of Natural Sciences of Philadelphia, 6:10-28, 1852.

Duvic, B. \& Soderhall, K. Purification and characterization of a beta 1,3 glucan binding protein from plasma of the crayfish Pacifastacus leniusculus. J. Biol. Chem., 265:9327-32, 1990.

Eschscholtz, F. F. Descriptio novae Astacorum speciei Rossicae. Memoires de la Societe Imperiale des Naturalistes du Moscu, 6:109-10, 1823.

Farmer, A. S. The functional morphology of the mouthparts and pereiopods of Nephrops norvegicus (L) (Decapoda: Nephropidae). J. Nat. Hist., 8:121-42, 1974.

Felgenhauer, B. E. \& Abele, L. G. Ultrastructure and functional morphology of feeding and associated appendages in the tropical fresh-water shrimp Atya innocous (Herbst) with notes on its ecology. J. Crustacean Biol., 3:336-63, 1983.

Firkins, I. Environmental tolerances of three species of freshwater crayfish. PhD Thesis. Nottingham University, 1993. pp.288.

Gledhill, T.; Sutcliffe, D. W. \& Williams, W. D. Freshwater Biological Association, Sci. Publ., 52:1-173, 1993.

Guan, R. Z. Ecological studies on the crayfish Pacifastacus leniusculus (Dana). Unpublished PhD thesis, University of Buckingham, 1995. pp.186.

Harlioglu, M. M. Comparative biology of the signal crayfish, Pacifastacus leniusculus (Dana), and the narrow-clawed crayfish, Astacus leptodactylus Eschscholtz. PhD Thesis, University of Nottingham, UK, 1996. pp.435.

Harlioglu, M. M. Incisor ridge modification of the mandibles in freshwater crayfish Astacus leptodactylus. Aquaculture Int., 8:443-53, 2000.

Harlioglu, M. M. The first report on the occurrence of twins in freshwater crayfish, Pacifastacus leniusculus (Decapoda, Astacoidea). Folia biol. (Kraków), 50:2156, 2002.
Harlioglu, M. M. Differences in the crista dentata structure of the ischium of the third maxilliped in Astacus leptodactylus (Eschscholtz, 1823). Folia biol., 51:111-6, 2003.

Harlioglu, M. M. \& Holdich, D. M. Meat yields in the introduced crayfish, Pacifastacus leniusculus and Astacus leptodactylus, from British waters. Aquacult. Res., 32:4117, 2001.

Harlioglu, M. M. \& Harlioglu, A. G. The harvest of freshwater crayfish, Astacus leptodactylus (Eschscholtz, 1823) in Turkey. Rev. Fish Biol. Fish, 14: 415-9, 2004.

Henry, R. P. \& Wheatly, M. G. Dynamics of salinity adaptations in the euryhaline crayfish Pacifastacus leniusculus. Physiological Zool., 61:260-71, 1988.

Hindley, J. P. R. \& Alexander, C. G. Structure and function of the chelate pereiopods of the banana prawn Penaeus merguiensis. Marine Biol., 48:153-60, 1978.

Hobbs, H. H. Jr. A rewiew of the crayfish genus Astacoides (Decapoda: Parastacidae). Smithsonian Contributions to Zoology, 443:1-50, 1987.

Hobbs, H. H. Crayfish distribution, adaptive radiation and evolution. In : Holdich, D. M. \& Lowery, R. S. (eds). Freshwater Crayfish: Biology, Management and Exploitation. London, Chapman and Hall, 1988. pp.11-51.

Holdich, D. M. Crayfish nomenclature and terminology: recommendations for uniformity. Finnish Fish Res., 14:149-55, 1992.

Holdich, D. M. The negative effects of established crayfish introductions. In: Ghrardi, F. \& Holdich, D. M. Eds. Crayfish in Europe as Alien Species. How to Make the Best of a Bad Situation? Balkema, Rotterdam/Brookfield, 1999. pp.31-47.

Holdich, D. M. Present distribution of crayfish in Europe and some adjoining countries. Bull. Fr. Pêche Piscic., 367:611$50,2002$.

Holdich, D. M. \& Reeve, I. D. Functional morphology and anatomy. In: Holdich, D. M. \& Lowery, R. S. Eds. Freshwater crayfish: biology, management and exploitation. London, Chapman and Hall, 1988. pp.1151.

Holdich, D. M. \& Reeve, I. D. Alien crayfish in British waters. Final report on GR3/6842 for Natural Environment Research Council, 1991. p38. 
HARLIOGLU, M. M. A scanning electron microscopic study on the appendage morphology of Astacus leptodactylus (Eschscholtz, 1823) and Pacifastacus leniusculus (Dana, 1852) (Crustacea: Decapoda: Astacoidea). Int. J. Morphol., 26(4):1035-1051, 2008.

Holdich, D. M.; Harlioglu, M. M. \& Firkins, I. Salinity adaptations of crayfish in British waters with particular reference to Austropotamobius pallipes, Astacus leptodactylus and Pacifastacus leniusculus. Estuarine, coastal and shelf science, 44:147-54, 1997.

Laurent, P. J. \& Forest, J. Donnees sur les ecrevisses qu'an peut rencontrer en France. Pisciculture Francaise, 56:2540, 1979.

Linnaeus, C. Systema naturae per regna tria naturae, secundum classes, ordines, genera, species, cum characteribus, differentiis, synonymis, locis. $10^{\text {th }} \mathrm{Ed}$. Holmiae, Laurentii Savii, 1758.

Lowery, R. S. \& Holdich, D. M. Pacifastacus leniusculus in North America and Europe, with details of the distribution of introduced and native crayfish species in Europe. In: Holdich, D. M. \& Lowery, R. S. Eds. Freshwater Crayfish: Biology, Management and Exploitation. London, Croom Helm, 1988. pp.283-308.

Kopacek, P.; Grubhoffer, L. \& Söderhall, K. Isolation and characterization of a hemagglutinin with affinity for lipopolysaccharides from plasma of the crayfish Pacifastacus leniusculus. Dev. Comp. Immunol., 17:407$18,1993$.

Köksal, G. Astacus leptodactylus in Europe. In: Holdich, D. M. \& Lowery, R. S. Eds. Freshwater Crayfish: Biology, Management and Exploitation. London, Croom Helm, 1988. pp. 365-400.

Momot, W. T. Redefining the role of crayfish in aquatic ecosystem. Rev. Fish Sci., 3:33-63, 1995.

Mura, G. \& Caldo, L. D. A scanning electron microscopic study of the molar surfaces of the mandibles in Branchinella spinosa H. Milne Edwards (Branchiopoda) with some remarks on the taxonomical significance of this character. Crustaceana, 64:326-36, 1993.

National Rivers Authority (NRA). A Guide to Identifying Freshwater Crayfish in Britain and Ireland. England, NRA, 1994.

Pennack, R. W. Fresh-water invertebrates of the United States. New York, John Wiley \& Sons, 1978.

Persson, M.; Cerenius, L. \& Söderhall, K. The influence of hemocyte number on the resistance of the crayfish Pacifastacus leniusculus Dana to the parasitic fungus Aphanomyces astaci. J. Fish Dis., 10:471-7, 1987.
Skurdal, J. \& Taugbol, T. Crayfish of commercial importanceAstacus. In: Holdich, D. M. (Ed.) Biology of Freshwater Crayfish. Oxford, Blackwell Science, 2002. pp.467-510.

Solon, M. H. \& Cobb, J. S. The external morphology and distribution of cuticular hair organs on the claws of the American lobster, Homarus americanus (MilneEdwards). J. Exp. Mar. Bio. Ecol., 48:205-15, 1980.

Thomas, W. J. The setae of Austropotamobius pallipes (Crustacea: Astacidae). J. Zool., 160:91-142, 1970.

Tierney, J. A. I nvidual variation and taxonomic significance of the seminal receptacle of the crayfish, Orconectes propinquus (Girard) (Decapoda Cambaridae). Crustaceana, 43:284-95, 1982.

Tyson, G. E. \& Sullivan, M. L. A scanning electron microscopic study of the molar surfaces of the mandibles of the brine shrimp ( $\mathrm{Cl}$. Branchiopoda: O. Anostraca). J. Morphol., 170:239-51, 1981.

Vigneux, E.; Keith, P. \& Noel, P. Atlas preliminaire des Crustaces Decapodes d'eau douce de France. Coll. Patrimoines Naturels, 14:55, 1993.

Warner, G. F. \& Green, E. I. Choice and consumption of aquatic weeds by signal crayfish (Pacifastacus leniusculus). Freshwater Crayfish, 8:360-3, 1995.

Warner, G. F.; Wood, J. C. \& Orr-Ewing, R. H. Signal crayfish (Pacifastacus leniusculus) feeding on pond snails: optimal foraging. Freshwater Crayfish, 8:352-9, 1995.

Correspondence to:

Prof. Dr. Muzaffer M. Harlioglu

Fisheries Faculty,

Fırat University,

23119, Elazıg

TURKEY

Tel(work): 00904242370000 ext: 4054

Fax: 00904242386287

Email: mharlioglu@firat.edu.tr

Received: 20-05-2008

Accepted: 22-08-2008 
